
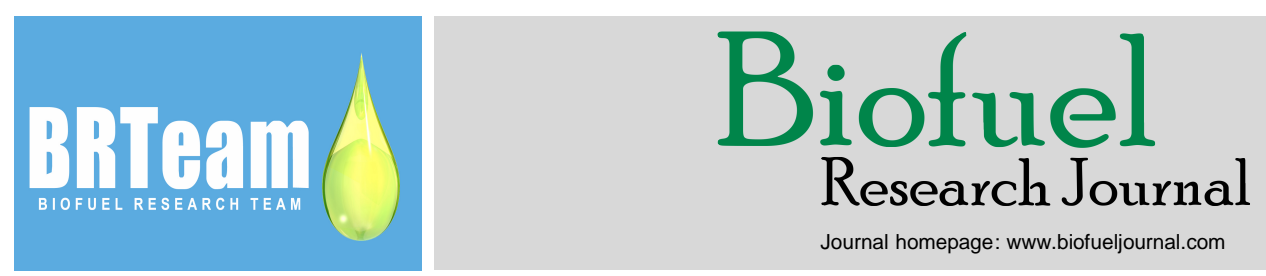

Journal homepage: www.biofueljournal.com

Review Paper

\title{
A review on the application of nanomaterials in improving microbial fuel cells
}

\author{
Mehrdad Mashkour $^{1}$, Mostafa Rahimnejad $^{1, *}$, Fereshteh Raouf $^{2}$, Nahid Navidjouy $^{3}$ \\ ${ }^{1}$ Biofuel \& Renewable Energy Research Center, Faculty of Chemical Engineering, Babol Noshirvani University of Technology, Babol, Iran. \\ ${ }^{2}$ Faculty of Engineering, Guilan University, Rasht, Iran. \\ ${ }^{3}$ Department of Environmental Health Engineering, Urmia University of Medical Sciences, Urmia, Iran.
}

\section{HIGHLIGHTS}

$>$ Nanomaterials and their roles in improving microbial fuel cells (MFCs) are reviewed. $>$ Significant effects of nanomaterials on growing active biofilm and electron transfer are discussed. $>$ Nanomaterials lead to higher catalytic activity for electrodes, and higher proton conductivity, and less biofouling for membranes.

$>$ Inexpensive and high-performance nanocomposites for more practical MFC applications are presented and discussed.

$>$ Future perspectives of using nanomaterials in MFCs are explained.

\section{GRAPHICAL ABSTRACT}

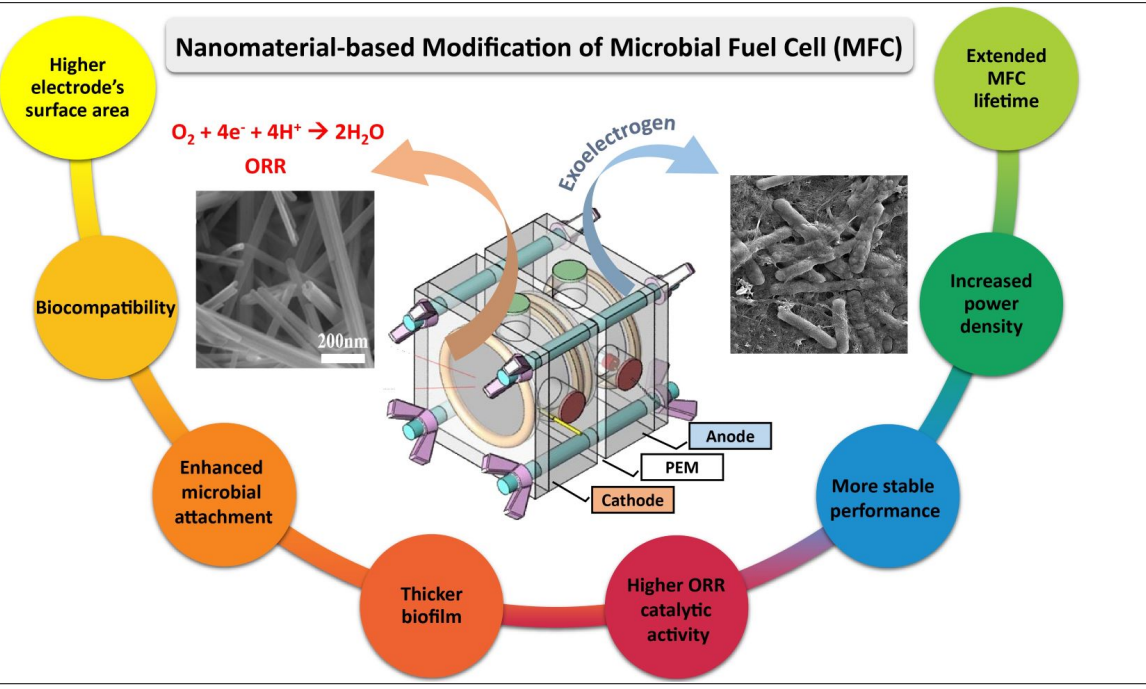

\begin{abstract}
Materials at the nanoscale show exciting and different properties. In this review, the applications of nanomaterials for modifying the main components of microbial fuel cell (MFC) systems (i.e., electrodes and membranes) and their effect on cell performance are reviewed and critically discussed. Carbon and metal-based nanoparticles and conductive polymers could contribute to the growth of thick anodic and cathodic microbial biofilms, leading to enhanced electron transfer between the electrodes and the biofilm. Extending active surface area, increasing conductivity, and biocompatibility are among the significant attributes of promising nanomaterials used in MFC modifications. The application of nanomaterials in fabricating cathode catalysts (catalyzing oxygen reduction reaction) is also reviewed herein. Among the various nanocatalysts used on the cathode side, metalbased nanocatalysts such as metal oxides and metal-organic frameworks (MOFs) are regarded as inexpensive and highperformance alternatives to the conventionally used high-cost Pt. In addition, polymeric membranes modified with hydrophilic and antibacterial nanoparticles could lead to higher proton conductivity and mitigated biofouling compared to the conventionally used and expensive Nafion. These improvements could lead to more promising cell performance in power generation, wastewater treatment, and nanobiosensing. Future research efforts should also take into account decreasing the production cost of the nanomaterials and the environmental safety aspects of these compounds.
\end{abstract}

(c) 2021 BRTeam. All rights reserved.

* Corresponding author at: Tel.: +98 1132320740

E-mail address: rahimnejad@nit.ac.ir ; rahimnejad_mostafa@yahoo.com

Please cite this article as: Mashkour M., Rahimnejad M., Raouf F., Navidjouy N. A review on the application of nanomaterials in improving microbial fuel cells. Biofuel Research Journal 30 (2021) 1400-1416. DOI: 10.18331/BRJ2021.8.2.5 


\section{Contents}

1. Introduction.

2. Nanomaterials in MFC's compartments.

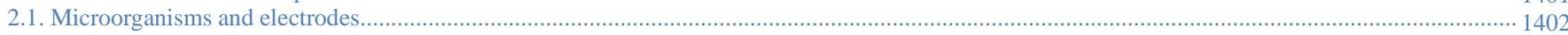

2.1.1. Effects of nanomaterials on exoelectrogens and anode performance

2.1.2. Effect of nanomaterials on electrotrophs and cathode performance

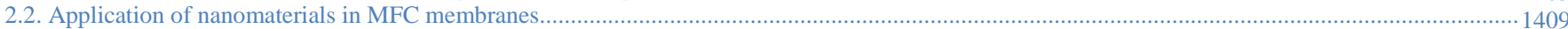

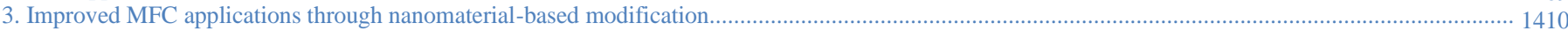

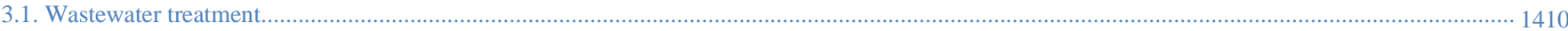

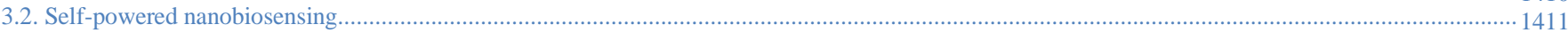

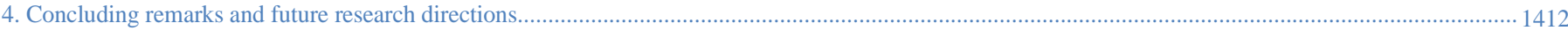

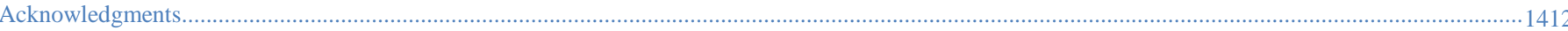

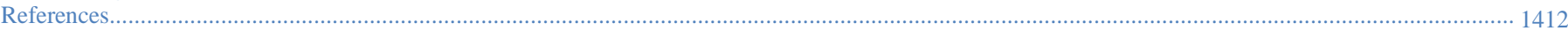

\begin{tabular}{|c|c|}
\hline \multicolumn{2}{|l|}{ Abbreviations } \\
\hline $3 \mathrm{D}$ & Three-dimensional \\
\hline $\mathrm{AgNPs}$ & Silver nanoparticles \\
\hline AuNPs & Gold nanoparticles \\
\hline $\mathrm{BC}$ & Bacterial cellulose \\
\hline BOD & Biological oxygen demand \\
\hline brGO & Biologically reduced graphene oxide \\
\hline CNT & Carbon nanotubes \\
\hline COD & Chemical oxygen demand \\
\hline CoNPs & Cobalt nanoparticles \\
\hline DCMFC & Dual-chamber microbial fuel cell \\
\hline EET & Extracellular electron transfer \\
\hline EIS & Electrochemical impedance spectroscopy \\
\hline FeCNPs & Iron carbide nanoparticles \\
\hline GDE & Gas diffusion electrode \\
\hline GO & Graphene oxide \\
\hline IR & Internal resistance \\
\hline MEA & Membrane electrode assembly \\
\hline MES & Microbial electrosynthesis \\
\hline MFC & Microbial fuel cell \\
\hline MOFs & Metal-organic frameworks \\
\hline MWCNTs & Multi-walled carbon nanotubes \\
\hline NiNPs & Nickel nanoparticles \\
\hline NPs & Nanoparticles \\
\hline $\mathrm{NZ}$ & Nano-zycosil \\
\hline ORR & Oxygen reduction reaction \\
\hline PANI & Polyaniline \\
\hline PEDOT & Poly(3,4-ethylenedioxythiophene) \\
\hline PEDOT: PSS & $\begin{array}{l}\text { Poly(3,4-ethylenedioxythiophene):polystyrene } \\
\text { sulfonate }\end{array}$ \\
\hline PEMs & Proton exchange membranes \\
\hline PES & Polyethersulfone \\
\hline PHF & Porous hollow fibers \\
\hline rGO & Reduced graphene oxide \\
\hline SCMFC & Single chamber microbial fuel cell \\
\hline SPEEK & Sulfonated poly(ether ether ketone) \\
\hline SPSEBS & $\begin{array}{l}\text { Sulfonated polystyrene ethylene butylene } \\
\text { polystyrene }\end{array}$ \\
\hline SS & Stainless steel \\
\hline $\mathrm{sTiO}_{2}$ & Sulfonated $\mathrm{TiO}_{2}$ \\
\hline $\mathrm{WO}_{3}$ & Tungsten oxide \\
\hline ZnONPs & Zinc oxide nanoparticles \\
\hline \multicolumn{2}{|l|}{ Nomenclatures } \\
\hline $\mathrm{R}_{\mathrm{ct}}$ & Charge transfer resistance \\
\hline
\end{tabular}

\section{Introduction}

Microbial fuel cell (MFC) is one of the potential sources to supply renewable energy. In MFCs, microorganisms serve as biocatalysts in the oxidation reaction of substrates, i.e., organic materials (Izadi et al., 2015; Ivars-Barceló et al., 2018; Masoudi et al., 2020). In better words, MFCs transform the chemical bond energy of organic compounds directly into electricity without passing through additional intermediate stages and the consequent losses (Kiran and Gaur, 2013; Xu et al., 2016; Berchmans, 2018). Therefore, similar to thermoelectric, photoelectric, thermionic devices, MFCs are also considered direct energy converters Mechanistically, there is a bio-electrochemical cycle in MFCs by which microbial and chemical processes occur (Zhang et al., 2018a). Bacteria consume the substrate anaerobically, resulting in the production of electrons and protons. Then, the generated electrons through the anode and the external circuit reach the cathode's surface, on which a chemical reaction takes place in the presence of protons and oxygen (Lu et al., 2015; Masoudi et al., 2021). Accordingly, in an MFC system, the main components include microorganisms, membranes, and electrodes, i.e., anode and cathode (Logan et al., 2015).

MFC is a multidisciplinary area of research that needs developments in biotechnology, electrochemistry, and material sciences. One of the most critical challenges in MFCs is the low electricity generation caused by the low efficiency of MFC components like electrodes, membrane, catalyst, and weak biofilm formation. Advanced materials fabricated through the recent developments in nanotechnology have played a considerable role in improving MFCs (Ghasemi et al., 2013). Materials in the nanoscale represent novel properties. For instance, they can accelerate microorganisms' biocatalytic activity by providing a high surface area for biofilm formation. Moreover, the oxygen reduction reaction (ORR) rate can be improved by nanoscale carbon or metal catalysts (Santoro et al., 2014). While on the other hand, the antibacterial properties of nanomaterials like metal oxides increase air-cathode lifetime (Yang et al., 2016). Nanomaterials have also been widely used in producing MFC electrodes to achieve a more significant number of active reaction sites. These improvements have led to higher performance MFCs for electricity generation applications, wastewater treatment, and bio-sensing.

Table 1 tabulates the various aspects of nanotechnology applications in MFCs covered by the present review compared to the review articles published over the last several years (2015-2021). To the best of the authors' knowledge, this is the first paper comprehensively and simultaneously discussing the impacts of nanotechnology on the performance of the MFC's main compartments and most of its known applications. The benefits and drawbacks of different nanomaterials are thoroughly explained. Also, improvements in MFCs for electricity generation, self-powered nanobiosensing, and wastewater treatment by considering the effect of nanomaterial modifiers are discussed.

\section{Nanomaterials in MFC's compartments}

Improving MFC's performance is proportional to enhancing the features of its constituents, i.e., microorganisms, electrodes (anode and cathode), and membrane. Nanomaterials can serve this purpose; Table 2 tabulates the potential effects of nanotechnology on improving the attributes of different 
Table 1.

Comparing the present review paper with previously published reviews (2015-2021) on the application of nanotechnology in MFCs.

\begin{tabular}{|c|c|c|c|c|c|c|c|c|c|}
\hline \multicolumn{4}{|c|}{ Nanotechnology in MFC compartments } & \multicolumn{5}{|c|}{ Nanotechnology in MFC applications } & \multirow[b]{2}{*}{ Reference } \\
\hline $\begin{array}{c}\text { Biofilm- } \\
\text { nanomaterial } \\
\text { interaction }\end{array}$ & Anode & Cathode & Membrane & $\begin{array}{l}\text { Electricity } \\
\text { generation }\end{array}$ & $\begin{array}{c}\text { Microbial } \\
\text { electrosynthesis }\end{array}$ & $\begin{array}{c}\text { Biohydrogen } \\
\text { production }\end{array}$ & $\begin{array}{c}\text { Wastewater } \\
\text { treatment }\end{array}$ & $\begin{array}{c}\text { Self-powered } \\
\text { Nanobiosensing }\end{array}$ & \\
\hline$x$ & $\sqrt{ }$ & $\sqrt{ }$ & $x$ & $\sqrt{ }$ & $\times$ & $\times$ & $\times$ & $\times$ & Ci et al. (2015) \\
\hline$\times$ & $\times$ & $\sqrt{ }$ & $\times$ & $\sqrt{ }$ & $\times$ & $\times$ & $\times$ & $\times$ & Kannan et al. (2016)* \\
\hline$\times$ & $\sqrt{ }$ & $\times$ & $\times$ & $\sqrt{ }$ & $\times$ & $\times$ & $\times$ & $\times$ & Hindatu et al. (2017) \\
\hline$\sqrt{ }$ & $\times$ & $\times$ & $\times$ & $\times$ & $\times$ & $\times$ & $\times$ & $\times$ & Zhang, et al. (2018b) \\
\hline$\sqrt{ }$ & $\sqrt{ }$ & $\times$ & $x$ & $\times$ & $\times$ & $\times$ & $\times$ & $\times$ & Mouhib et al. (2019) \\
\hline$\times$ & $\times$ & $\times$ & $\sqrt{ }$ & $\sqrt{ }$ & $\times$ & $\times$ & $\sqrt{ }$ & $x$ & Shabani et al. (2020) \\
\hline$\sqrt{ }$ & $\sqrt{ }$ & $\sqrt{ }$ & $\sqrt{ }$ & $\sqrt{ }$ & $\times$ & $\sqrt{ }$ & $x$ & $\times$ & Olabi et al. (2020)* \\
\hline$\times$ & $\sqrt{ }$ & $\times$ & $\times$ & $\sqrt{ }$ & $\times$ & $\times$ & $\times$ & $\times$ & Liu et al. (2020) \\
\hline$\times$ & $\sqrt{ }$ & $\sqrt{ }$ & $\times$ & $\sqrt{ }$ & $\times$ & $\times$ & $\times$ & $\times$ & Kaur et al. (2020) \\
\hline$\times$ & $\sqrt{ }$ & $\times$ & $x$ & $\sqrt{ }$ & $\times$ & $\times$ & $\times$ & $x$ & Cai et al. (2020a) \\
\hline$\times$ & $\sqrt{ }$ & $\sqrt{ }$ & $\times$ & $\sqrt{ }$ & $\times$ & $\times$ & $x$ & $\times$ & Narayanasamy et al. (2020) \\
\hline$\sqrt{ }$ & $x$ & $x$ & $x$ & $\times$ & $\times$ & $\times$ & $\times$ & $x$ & Wang et al. (2021) \\
\hline$\times$ & $\times$ & $\sqrt{ }$ & $\times$ & $\sqrt{ }$ & $\times$ & $\times$ & $\times$ & $\times$ & Peera et al. (2021) \\
\hline$\sqrt{ }$ & $\sqrt{ }$ & $\sqrt{ }$ & $\sqrt{ }$ & $\sqrt{ }$ & $\sqrt{ }$ & $x$ & $\sqrt{ }$ & $\sqrt{ }$ & This review \\
\hline
\end{tabular}

$\sqrt{ }:$ Included

$\mathrm{x}$ : Not included

${ }^{*}$ For the case of graphene

Table 2.

Potential effects of nanotechnology on enhancing the attributes of different constituents of MFC systems.

\begin{tabular}{ll}
\hline MFC constituent & Potential effects of nanotechnology \\
\hline Microorganisms & $\begin{array}{l}\text { Growth rate, bacteria attachment, extracellular electron transfer, } \\
\text { the activity of biofilm in a redox reaction, biofilm resistance }\end{array}$ \\
Anode & $\begin{array}{l}\text { Conductivity, high surface area, porosity, charge transfer, } \\
\text { capacitance, biocompatibility }\end{array}$ \\
Cathode & $\begin{array}{l}\text { Conductivity, high surface area, porosity, charge transfer, } \\
\text { capacitance, oxygen reduction reaction (ORR) rate, gas diffusion, } \\
\text { anti-fouling }\end{array}$ \\
Membrane & $\begin{array}{l}\text { Proton conductivity, oxygen cross-over, water uptake, separation, } \\
\text { anti-fouling }\end{array}$ \\
\hline
\end{tabular}

MFC parts. Nevertheless, the cost of nanomaterials might still be a limiting factor, and hence, efforts should be put into developing low-cost nanomaterials of outstanding features.

\subsection{Microorganisms and electrodes}

Microorganisms utilized in MFCs are classified into two main groups: exoelectrogens on the anode and electrotrophs on the cathode (biocathode) (Fig. 1a) (Logan et al., 2006 and 2019). Exoelectrogens are vital and form a biofilm on the anode surface to decompose organic substrates like glucose, acetate, and waste materials to generate electrons and protons. Thus, this group is necessary for electricity generation. These microorganisms can transport electrons from electron donors (substrate) to electrode surfaces by various mechanisms, including direct contact, nano-wires, and mediators produced by them (Logan, 2009). Figure 1b demonstrates the mentioned electron transport mechanisms. Electrotrophs (electrotrophic microorganisms) need electrons as feed to grow and use various electron acceptors like carbon dioxide. These microorganisms (Fig. 1c) are instrumental in the reactions taking place on the cathode. Electrotrophs play a vital role as a biocathode in microbial electrosynthesis (MES) systems.

\subsubsection{Effects of nanomaterials on exoelectrogens and anode performance}

As mentioned earlier, exoelectrogens in anodic biofilms form active sites for the oxidation of organic molecules fed to MFCs. The properties of the anode surface are of great importance for the colonization of exoelctrogenic bacteria by influencing the transfer of electrons and bacterial attachment (Lv et al., 2019; Palanisamy et al., 2019). An ideal MFC anode material has to expedite the flow of electrons and accelerate the attachment of microbes using conduction. Graphite (plate, rod, and brush), carbon paper, carbon felt, and carbon cloth are the conventional carbon-based materials utilized as anodes in MFC systems (Ghasemi et al., 2013) and are commercially available. In general, carbon as an anti-corrosion material with good conductivity is considered suitable for electrode fabrication in MFC. However, using conventional anodes, electron movement from microbial biofilm to the electrode surface is restricted due to bacteria's weak attachment. This issue impacts the MFC function by decreasing the power output and consequently hinders the practical utilization of the MFC technology. The other significant shortcoming is high internal resistance (IR), resulting in a low rate of charge transfer and high-cost materials.

Inexpensive nanomaterials can provide an extended surface area for bacteria growth on the anode and enhance microbial attachment. This improvement (i.e., enhanced exoelectrogens colonization) through increased extracellular electron transfer (EET) and substrate metabolism lead to augmented function and effectiveness of the MFC (Patel et al., 2019; Salar-García and Ortiz-Martínez, 2019). The increase in the number of exoelectrogenic colonies boosts the redox activity of anodic biofilm, and hence, more electrons and protons are generated. Table 3 tabulates the effects of different nanomaterials used for modifying anodes and the consequent improvements in the power density of the investigated MFC systems, including various exoelectrogens.

Multi-walled carbon nanotubes (MWCNTs) are among the most widely used nanomaterials for anode modification. They can provide an excellent active surface for microbial attachment. As presented in Table 3, Nambiar et al. (2009) utilized MWCNTs for improving the growth of Enterobacter cloacae on a commercial carbon sheet anode in a dual-chamber MFC (DCMFC) with a platinum-coated carbon sheet cathode. In this work, a maximum power density increase of $256 \%$ was achieved using the MWCNTs modified anode rather than the bare carbon sheet. The authors 
$\mathbf{e}$
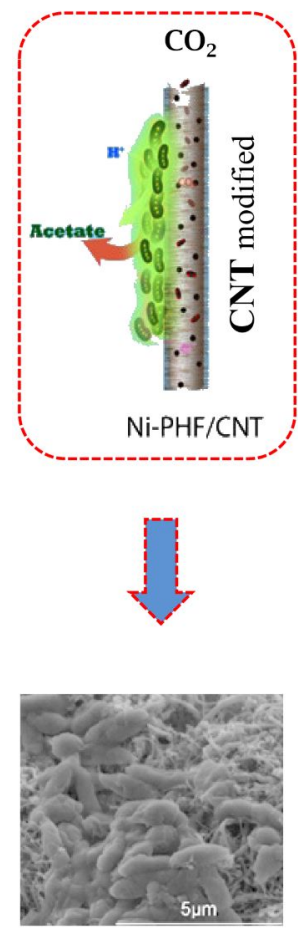
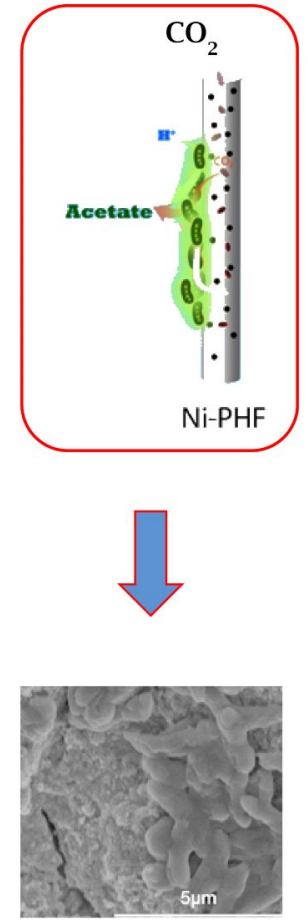

b
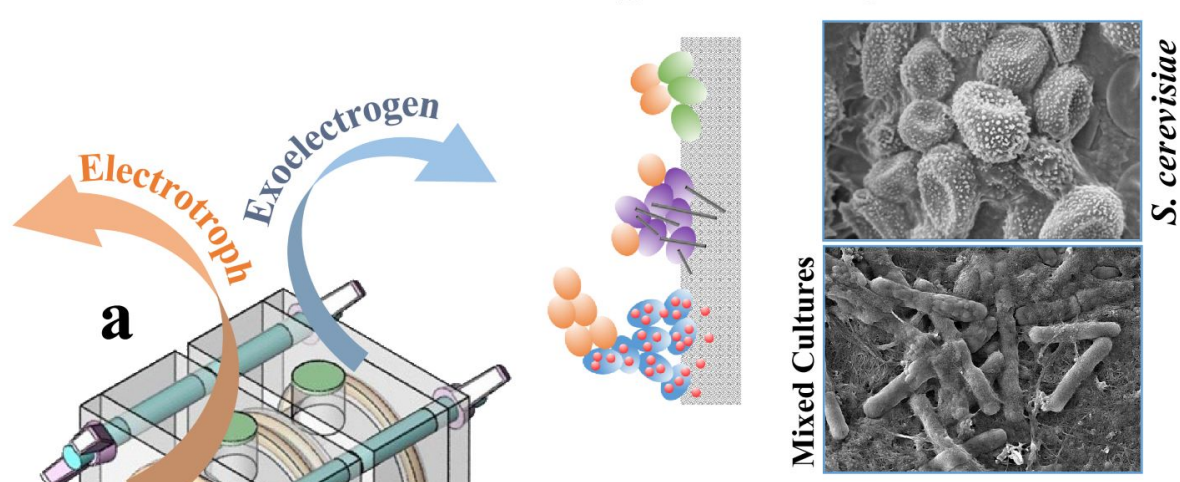

d

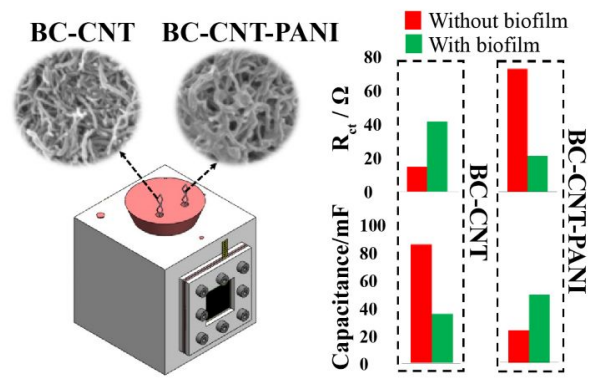

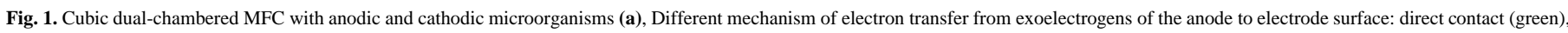

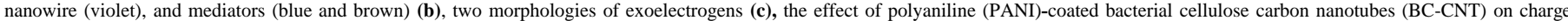

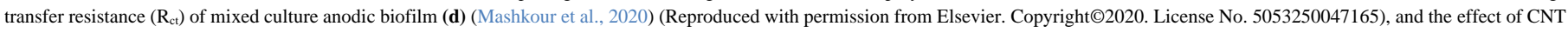
on Sporomusa ovate cathodic biofilm formation (e) (Bian et al., 2018) (Reproduced with permission from Royal Society of Chemistry. Copyright@2018. License No. 1112686-1).

attributed the improvement made to the extended highly conductive surface area on the carbon sheet obtained using a high concentration of MWCNTs ink $(10 \mathrm{mg} / \mathrm{mL})$ and chitosan as a green binder (Nambiar et al., 2009). Despite the increased surface area for bacterial colonization, these nanomaterials have been reported as toxic at specific concentrations against bacteria. A recent work investigating the MWCNT's toxicity effect on microbial growth of Geobacter sulfurreducens biofilm revealed that the maximum MWCNTs concentration for improving anodic biofilm performance (i.e., highest power and current density compared to bare carbon sheet) was found to be $0.1 \mathrm{mg} / \mathrm{mL}$ (Jiang et al., 2018). However, further increments in MWCNTs concentration resulted in anodic biofilm's weak performance, suggesting that the MWCNTs concentration must have exceeded its toxic threshold (Jiang et al., 2018).

The following reasons could explain the significantly different optimal concentrations reported by these two studies; 1) the differences in the biofilms developed and 2) the differences in the time of measurements. As for the latter, it is imperative to allow the microbial colonization process (biofilm formation) to complete before performance outputs are measured. In better words, high power density values might be obtained on the onset of MFC operation due to the high conductivity and surface area of the nanomaterials-based anode; however, performance deterioration would likely occur in response to low biocompatibility of the nanomaterials or their higher-than-thresholdconcentration. Under toxic conditions, nanomaterials could deactivate microbial populations colonized on the anode leading to increased anode resistance and deteriorated performance parameters. So, the findings reported by Nambiar et al. (2009) could have been more conclusive if the authors had considered a longer colonization process.

To better understand the toxicity effect of MWCNTs $(0.4 \mathrm{mg} / \mathrm{mL})$ on anodic biofilm, a more recent comprehensive research was performed by Mashkour et al. (2020) using electrochemical impedance spectroscopy (EIS). They utilized two MWCNTs-coated bacterial cellulose (BC) based anodes (BC-CNT) in two similar single-chamber MFCs (SCMFCs) with the same mixed-cultures as anodic bacteria. They studied charge transfer resistance $\left(\mathrm{R}_{\mathrm{ct}}\right)$ of the anode before the colonization process, after three weeks of colonization when biofilm was formed on the anode, and after $50 \mathrm{~d}$. The BC-CNT without biofilm showed the lowest resistance, while in response to microbial colonization, the $\mathbf{R}_{\mathrm{ct}}$ showed an increasing trend (Mashkour et al., 2020). These findings were indicative of the toxicity effect of MWCNTs (at the tested concentration of $0.4 \mathrm{mg} / \mathrm{mL}$ ) on the mixed-culture biofilm and were approximately in agreement with the data reported by Jiang et al. (2018) To mitigate the toxicity effects of MWCNTs on the developed anode biofilm and to enhance its activity, Mashkour et al. (2020) tried to modify MWCNTs using biocompatible nanomaterials like polyaniline (PANI) (Fig. 1d). The authors claimed that the modification could successfully mitigate the toxicity of the nanocomposite and consequently decrease the $\mathrm{R}_{\mathrm{ct}}$.

Other carbon-based nanomaterials have also been used for anode modification. For instance, reduced graphene oxide (rGO) nanosheets have been recently utilized for improving the exoelectrogenic biofilm activity of Shewanella putrefaciens in an MFC system (Zhu et al., 2019). Graphene oxide (GO) was dispersed in an anolyte solution of bacteria and was then reduced on carbon felt in situ biologically (br-GO). The power density generated by the modified anode stood at $240 \mathrm{~mW} / \mathrm{m}^{2}$, which was substantially higher than the value recorded for the unmodified carbon $\left(0.015 \mathrm{~mW} / \mathrm{m}^{2}\right)$ (Zhu et al., 2019). Mechanistically, br-GO must have formed a high-surface-area conductive bridge between the microbial biofilm and the carbon felt fibers, facilitating the extracellular transfer of electrons between them. Moreover, br-GO was found highly biocompatible, which must have also contributed to the high affinity of the bacterial populations to grow at higher rates, more effectively colonize, and form a thicker layer of active biofilm on the anode (Zhu et al., 2019).

Various other biocompatible nanomaterials have also been studied for anode modification to boost biofilm formation and activity. For instance, a mixture of nickel nanoparticles (NPs), Poly(3,4-ethylenedioxythiophene) (PEDOT), and graphene was employed by Hernandez et al. (2019) to 
Table 3.

Effects of anode modifications using nanomaterials on the performance (power density) of different MFC systems with different exoelectrogens

\begin{tabular}{|c|c|c|c|c|c|c|c|}
\hline \multirow{2}{*}{$\begin{array}{l}\text { Exoelectrogenic } \\
\text { microorganisms }\end{array}$} & \multirow{2}{*}{$\begin{array}{c}\text { Device } \\
\text { configuration }\end{array}$} & \multirow{2}{*}{ Anode (Control) } & \multirow{2}{*}{$\begin{array}{l}\text { Anode (modified by } \\
\text { nanomaterials) }\end{array}$} & \multirow{2}{*}{ Cathode } & \multicolumn{2}{|c|}{ Power density $\left(\mathrm{mW} / \mathrm{m}^{2}\right)^{*}$} & \multirow{2}{*}{ Reference } \\
\hline & & & & & Control & Modified & \\
\hline Enterobacter cloacae & DCMFC & Carbon paper & $\begin{array}{l}\text { Multi-walled carbon nanotube } \\
\text { (MWCNTs) modified carbon } \\
\text { paper }\end{array}$ & Carbon sheet & \multicolumn{2}{|c|}{$256 \%$ improvement* } & Nambiar et al. (2009) \\
\hline Mixed culture & $\begin{array}{l}\text { Single-chamber } \\
\text { microbial fuel cell } \\
\text { (SCMFC) }\end{array}$ & Carbon cloth & $\begin{array}{l}\text { PANI-graphene modified carbon } \\
\text { cloth }\end{array}$ & $\mathrm{Pt} /$ carbon cloth & 454 & 884 & Huang et al. (2016) \\
\hline Mixed culture & DCMFC & Graphite plate & Wet BC-PANI & Graphite plate & 1 & 117 & Mashkour et al. (2016) \\
\hline Mixed culture & DCMFC & Graphite plate & Wet BC-Polypyrrole & Graphite plate & 1 & 136 & Mashkour et al. (2017a) \\
\hline Geobacter sulfurreducens & DCMFC & Carbon sheet & $\begin{array}{l}\text { Carbon nanotubes (CNTs) } \\
\text { modified carbon sheet }\end{array}$ & - & \multicolumn{2}{|c|}{$200 \%$ improvement } & Jiang et al. (2018) \\
\hline Mixed culture & SCMFC & Graphite & $\begin{array}{l}\text { Iron carbide nanoparticles-porous } \\
\text { graphite }\end{array}$ & $\mathrm{Pt} /$ carbon cloth & 997 & 1856 & Hu et al. (2019) \\
\hline Shewanella loihica PV-4 & DCMFC & $\begin{array}{l}\mathrm{TiO}_{2} \text { nano sheet/ } \\
\text { carbon cloth }\end{array}$ & $\begin{array}{l}\text { PANI modified } \mathrm{TiO}_{2} \text { nano sheet/ } \\
\text { carbon cloth }\end{array}$ & - & \multicolumn{2}{|c|}{$63 \%$ improvement } & Yin et al. (2019) \\
\hline Shewanella putrefaciens & $\begin{array}{l}\text { Dual-chamber } \\
\text { microbial fuel cell } \\
\text { (DCMFC) }\end{array}$ & Carbon felt & $\begin{array}{l}\text { Bio-reduced graphene oxide } \\
\text { modified carbon felt }\end{array}$ & Pt sheet & 0.015 & 240 & Zhu et al. (2019) \\
\hline Escherichia coli & DCMFC & $\begin{array}{l}\text { Stainless steel } \\
\text { (SS) }\end{array}$ & $\begin{array}{l}\text { Poly(3,4-ethylenedioxythiophene) } \\
\text { (PEDOT)/graphene/nickel-nanopa } \\
\text { rticles SS }\end{array}$ & Graphite & 1800 & 3200 & Hernández et al. (2019) \\
\hline Saccharomyces cerevisiae & SCMFC & Carbon felt & Gold nanoparticle-carbon felt & - & 381 & 2271 & Duarte et al. (2019) \\
\hline Mixed culture & SCMFC & $\begin{array}{l}\text { Bacterial } \\
\text { cellulose-CNTs } \\
(\mathrm{BC}-\mathrm{CNT})\end{array}$ & $\begin{array}{l}\text { Polyaniline (PANI) modified BC- } \\
\text { CNT }\end{array}$ & $\begin{array}{l}\text { Activated } \\
\text { carbon-SS }\end{array}$ & \multicolumn{2}{|c|}{$20 \%$ improvement } & Mashkour et al. (2020) \\
\hline Shewanella xiamenensis & DCMFC & BC-PANI & $\begin{array}{l}\text { Titanium dioxide modified BC- } \\
\text { PANI }\end{array}$ & Graphite & 137 & 179 & Truong et al. (2021) \\
\hline S. loihica PV-4 & DCMFC & Carbon felt & Iron oxide modified carbon felt & $\mathrm{Pt} /$ carbon paper & 220 & 797 & Yang et al. (2021) \\
\hline
\end{tabular}

* Only variations in power density (\%) were reported in some studies.

modify a stainless steel (SS) anode with E.Coli as anodic bacteria in a DCMFC. The high surface area of graphene and its good conductivity on the one hand and the high redox activity of PEDOT, on the other hand, provided the SS anode with suitable sites for exoelectrogenic activity. Also, NiNPs accelerated the anodic biofilm formation because of their biocompatibility. The generated power density was improved by around twice compared with bare SS anode (Hernández et al., 2019).

Gold NPs (AuNPs) were also used to modify anode electrode in an SCMFC by Duarte et al. (2019). Anodic biofilm activity of Saccharomyces cerevisiae on polyethyleneimine-functionalized carbon felt increased after the anode was coated by AuNPs. The modified anode led to an enhanced power density of $2271 \mathrm{~mW} / \mathrm{m}^{2}$ vs. $381 \mathrm{~mW} / \mathrm{m}^{2}$ recorded for the control. The authors performed an in-depth analysis using high-resolution scanning electron microscopy to shed light on the exact role of AuNPs. Anode surface analysis showed a strong interaction between the yeasts` external cellular membranes and the AuNPs but a weak one with the carbon fibers confirming the excellent biocompatibility of the former (Duarte et al., 2019). Moreover, the AuNPs attachment onto $S$. cerevisiae membrane could result in direct electron transfer. In other words, the high conductivity of AuNPs mimicks nanowires' behavior for the yeast biofilm, leading to enhanced activity. Despite the promising results obtained using AuNPs, it should be noted that they are costly materials and that this would limit their real-world application in MFC technology.

Inexpensive nanometals have been used to address the cost challenges associated with applying precious nanometals such as AuNPs. Iron carbide NPs (FeCNPs) were synthesized on carbon felt as an anode in an MFC with mixedculture bacteria (Hu et al., 2019). Compared with the bare carbon felt, the power density of the modified anode increased by about 200\% (Hu et al., 2019). FeCNPs could enrich the exoelectrogenic biofilm of mixed cultures and speed up the redox reaction. Moreover, the FeCNPs provided a much lower $\mathrm{R}_{\mathrm{ct}}$ than carbon felt. High activity of FeCNPs might also be attributed to the similar nature of microbial heme to $\mathrm{Fe}$, resulting in higher biocompatibility of the FeCNPs to anodic biofilms.

Nanocellulose is a low-cost group of useful materials for bacteria colonization. They can be coated and modified with a vast range of carbon, metal, and polymer-based materials to make this compound conductive for use in MFCs (Fig. 2). Mashkour et al. (2016 and 2017a) introduced a new generation of anode electrodes called hydrogel bio-anode. They fabricated porous hydrogel BC-based anodes coated by conductive polymers, i.e., PANI (Mashkour et al., 2016) and polypyrrole (Mashkour et al., 2017a). The capillary effect between the BC nanofibers resulted in permanent access of bacteria to nutrients and prevented bacteria spoilage and clogging of pores (Mashkour et al., 2013). The bio-anode improved the power density of the investigated MFCs significantly compared to the graphite plate (Mashkour et al., 2016 and 2017a). The biocompatibility of both BC and the conductive polymers contributed to a more effective adhesion of the bacteria onto the anode, facilitating electron transfer. Moreover, the bioanode led to higher redox activity, whose mechanism should be further investigated by future studies. It should be noted that the wet hydrogel electrode (bio-anode) used by Mashkour et al. (2016 and 2017a) possessed low $\mathrm{pH}$ values, which could have contributed to the excellent conductivity of the modified BC. However, the authors did not consider the effects of $\mathrm{pH}$ variations on the performance of the fabricated electrodes. Given the pH-dependent nature of conductive polymers (Hong and Park, 2005), different results could have been obtained if different $\mathrm{pH}$ values had been taken into consideration. This should also be a topic of future investigation.

Overall, for anode modification using nanomaterials, various properties of these compounds, including redox properties, conductivity, surface area, biocompatibility, and cost, should be considered. From an economic perspective, carbon-based nanomaterials, conductive polymers, and inexpensive nanometals could be regarded as excellent choices. It should 


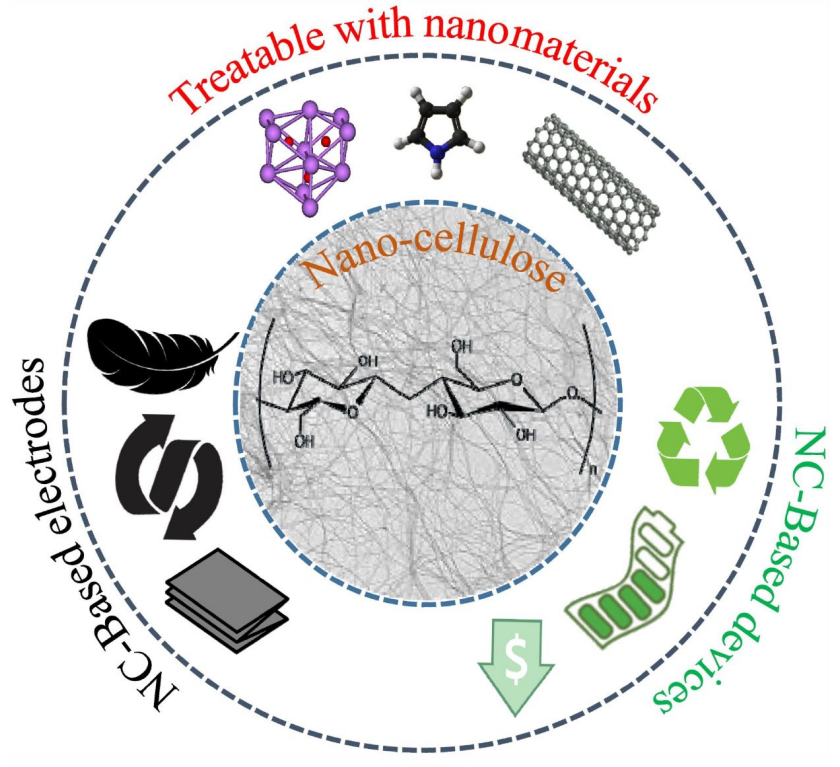

Fig. 2. A brief overview of nanocellulose and its features.

also be noted that the effect of nanomaterials might differ for each species of exoelectrogens as shown by Chen et al. (2020), and should be taken into consideration during experimental designs.

\subsubsection{Effect of nanomaterials on electrotrophs and cathode performance}

The effect of nanomaterials on electrotrophs' performance is generally similar to what is explained for exoelectrogens. In addition to those, nanomaterials can increase gas adsorption on the cathode side, leading to enhanced electrotrophic performance. This is essential in the electrosynthesis of chemicals in bioelectrochemical systems. Moreover, nanomaterials with photocatalytic properties might also benefit the electrotrophic activity by boosting the reaction taking place over the cathode. Table 4 presents the results of several case studies investigating the application of nanomaterials in MES systems for producing acetate by different kinds of electrotrophs.

For acetate production from $\mathrm{CO}_{2}$ in an MES system, Bian et al. (2018) modified the cathode surface with porous hollow fibers of nickel (Ni-PHF) and CNT in the presence of Sporomusa ovate (Fig. 1e). The porous structure of Ni-PHF could provide $S$. ovata with direct access to $\mathrm{CO}_{2}$ on the cathode surface. At the same time, the high specific area of CNT could increase $\mathrm{CO}_{2}$ adsorption by more than eleven times and improved charge transfer by boosting cathodic current density from 214 to $332 \mathrm{~mA} / \mathrm{m}^{2}$ (Bian et al., 2018). In a different study but using the same electrotroph, a reduced graphene oxide sheet was used as a cathode for microbial colonization (Aryal et al., 2017). The authors claimed that acetate production rate and current density were increased by 7 and 8 times, respectively, compared to the carbon paper electrode.

Compared to carbon cloth, the surface area of the cathodic biofilm of Clostridium ljungdahlii was expanded by 3.2 folds through incorporating graphene and CNT in a three-dimensional (3D) cathode structure (Han e al., 2019). The modified structure elevated the NADH/NAD ${ }^{+}$ratio, and the excess NADH could be used in $\mathrm{CO}_{2}$ fixation. Consequently, acetate production and cathodic current density increased by 5 and 4.4 times, respectively, compared to the values recorded for carbon cloth (Han et al. 2019). In a more recent study, carbon cloth was modified by GO and electro-polymerized conductive PEDOT to improve the interaction between Methanobacterium and $\mathrm{CO}_{2}$ for a higher acetate production rate (Li et al., 2020). The authors compared three types of modified carbon cloth, i.e., GO, PEDOT, and GO-PEDOT modified carbon cloth, as shown in Figure 3. They reported that the biofilm density increased due to the GO's high surface area, and a higher electron transfer rate from cathode to bacteria was obtained through the function of the conductive PEDOT ( $\mathrm{Li}$ et al., 2020).

Recently, a cathode modified by tungsten oxide $\left(\mathrm{WO}_{3}\right)$ and molybdenum oxide $\left(\mathrm{MoO}_{3}\right)$ NPs was reported used for a photo-assisted MES system. Serratia marcescens was utilized as an electrotroph to produce acetate from $\mathrm{HCO}_{3}$ (Fig. 4). The photocurrent generated by the nanoparticle oxidesmodified cathode was about five times higher than that of the bare carbon felt-based cathode. Photo-induced electrons placed on the conduction bands of the modified biocathode improved the hydrogen evolution reaction. The produced hydrogen promoted acetate production by the electrotroph $S$ marcescens (Cai et al., 2020b).

Overall, it could be concluded that the modification of cathode surface in MES systems using nanomaterials, by increasing surface area, could provide electrotrophs (responsible for producing chemicals) with more electrons and more gas molecules such as $\mathrm{CO}_{2}$. The latter is ascribed to the higher gas adsorbtion rates of the nanomaterial-based modified cathodes. It should be noted that for these advantages to work, the nanomaterials used in cathode modification are bound to be biocompatible so that electrotrophs can grow densely, forming a thick biofilm. Also, the adsorption capacity of

Table 4.

Effects of cathode modifications using nanomaterials on the performance (cathodic current density) of different MES systems with different electrotrphs.

\begin{tabular}{|c|c|c|c|c|c|c|c|}
\hline \multirow{2}{*}{$\begin{array}{l}\text { Electrotrophic } \\
\text { microorganisms }\end{array}$} & \multirow{2}{*}{ Device configuration } & \multirow{2}{*}{ Anode } & \multirow{2}{*}{$\begin{array}{l}\text { Cathode } \\
\text { (Control) }\end{array}$} & \multirow{2}{*}{ Cathode (modified by nanomaterials) } & \multicolumn{2}{|c|}{$\begin{array}{l}\text { Cathodic current density } \\
\qquad\left(\mathbf{m A} / \mathbf{m}^{2}\right)\end{array}$} & \multirow{2}{*}{ Reference } \\
\hline & & & & & Control & Modified & \\
\hline $\begin{array}{l}\text { Methanol-adapted } \\
\text { Sporomusa ovata }\end{array}$ & $\begin{array}{l}\text { Dual-chamber microbial } \\
\text { electrosynthesis } \\
\text { (DCMES) }\end{array}$ & Graphite stick & Carbon cloth & $\begin{array}{l}\text { Reduced graphene oxide- } \\
\text { tetraethylenepentamine modified carbon } \\
\text { cloth }\end{array}$ & 420 & 2358 & Chen et al. (2016) \\
\hline S. ovata & DCMES & Graphite stick & Carbon paper & Reduced graphene oxide paper & \multicolumn{2}{|c|}{$700 \%$ improvement* } & Aryal et al. (2017) \\
\hline S. ovata & DCMES & $\mathrm{IrO}_{2}$-carbon cloth & Nickel fibers & CNT modified porous nickel hollow fiber & 214 & 332 & Bian et al. (2018) \\
\hline Clostridium ljungdahlii & DCMES & - & Carbon cloth & Graphene-CNTs modified carbon cloth & 135 & 595 & Han et al. (2019) \\
\hline S. ovata & DCMES & Graphite stick & Cooper foam & $\begin{array}{l}\text { Reduced graphene oxide modified cooper } \\
\text { foam }\end{array}$ & \multicolumn{2}{|c|}{$300 \%$ improvement* } & Aryal et al. (2019) \\
\hline Autotrophic microbe & DCMES & Carbon felt & Carbon felt & $\mathrm{MnO}_{2}$-modified carbon felt & \multicolumn{2}{|c|}{$200 \%$ improvement* } & Anwer et al. (2019) \\
\hline Serratia marcescens & DCMES & Carbon rod & Carbon felt & $\begin{array}{l}\mathrm{WO}_{3} / \mathrm{MoO}_{3} \text { nanoparticles modified } \mathrm{g}-\mathrm{C}_{3} \mathrm{~N}_{4} \\
\text { carbon felt }\end{array}$ & 1500 & 2500 & Cai et al. (2020b) \\
\hline Methanobacterium & DCMES & Carbon felt & Carbon cloth & $\begin{array}{l}\text { Graphene oxide-PEDOT modified carbon } \\
\text { cloth }\end{array}$ & 840 & 2540 & Li et al. (2020) \\
\hline
\end{tabular}

* Only variations in cathodic current density (\%) were reported in some studies. 


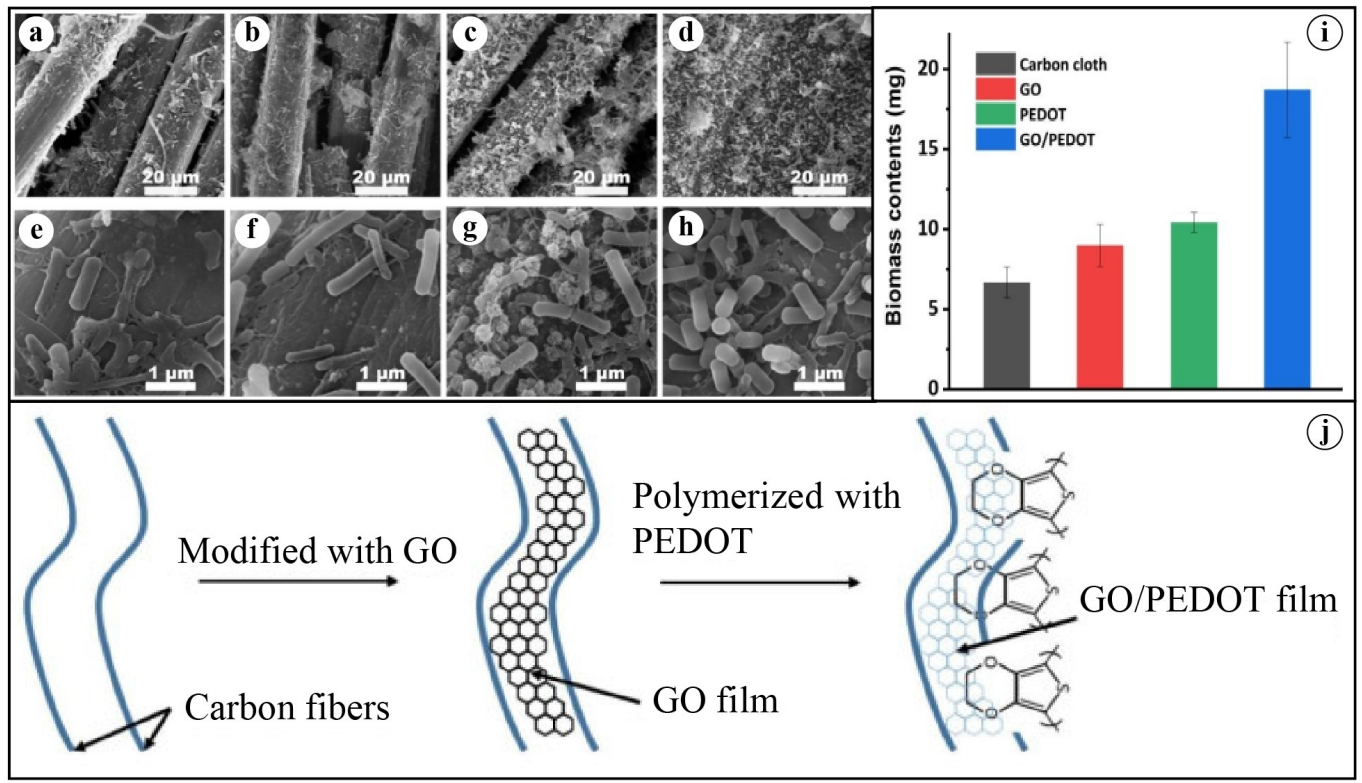

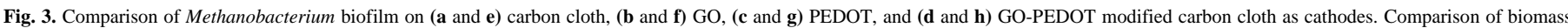

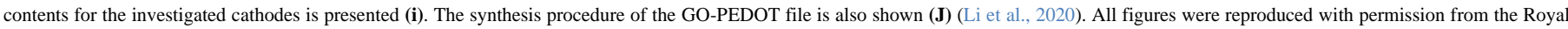
Society of Chemistry Copyright $\odot 2020$. License No.: 1112703-1.

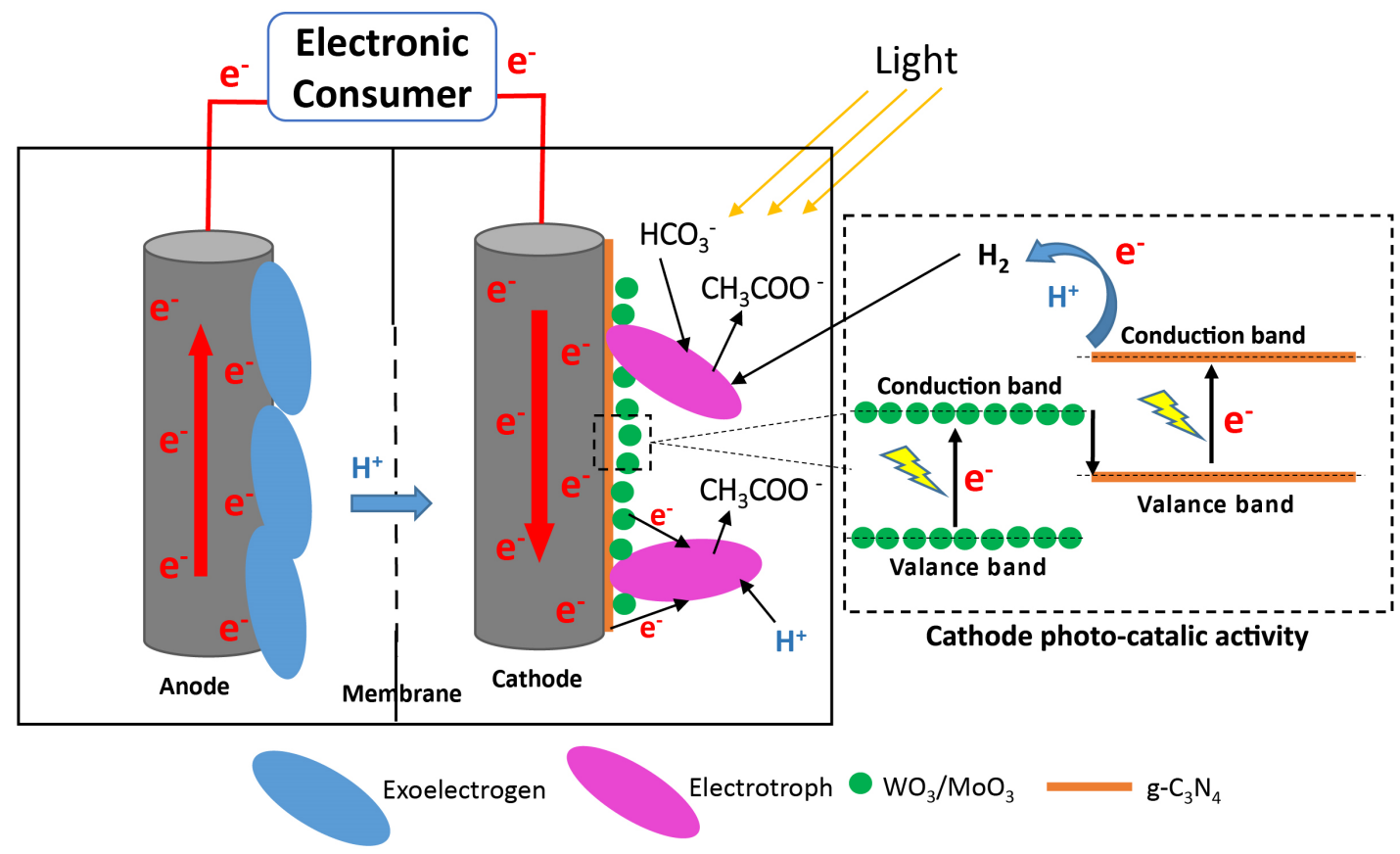

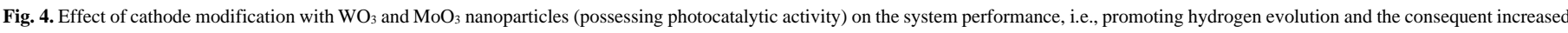
acetate production by the electrotroph Serratia marcescens. Adapted from Cai et al. (2020b).

the utilized nanomaterials is vital in providing electrotrophs with additional gas molecules in reaction sites existing over the biocathode.

In MFC systems, ORR is desired to occur at the highest rates possible, signifying the critical role of catalysts (i.e., catalytic activity). On the other hand, the cost of the catalyst used for catalyzing ORR on the cathode is significantly important to achieve an economically viable system. Pt is a known high-performance catalyst used in various types of fuel cells. However, its use in MFC is limited because of its high cost and bacteria's poisonous effect on the Pt-based catalysts (Mashkour and Rahimnejad, 2015; Xue et al., 2020). Inexpensive nanomaterials are considered excellent choices to achieve the mentioned objective by extending the surface of the cathode (Fig. 5).

Metal oxides nanomaterials are among the promising alternatives to $\mathrm{Pt}$ for use as cathode catalysts. Tofighi et al. (2019) coated carbon cloth with a mixture of $\alpha-\mathrm{MnO}_{2}-\mathrm{GO}$ and activated carbon and used it as the cathode in a DCMFC. The authors argued that the modified cathode possessed a substantially higher catalytic activity resulting in an increased power 


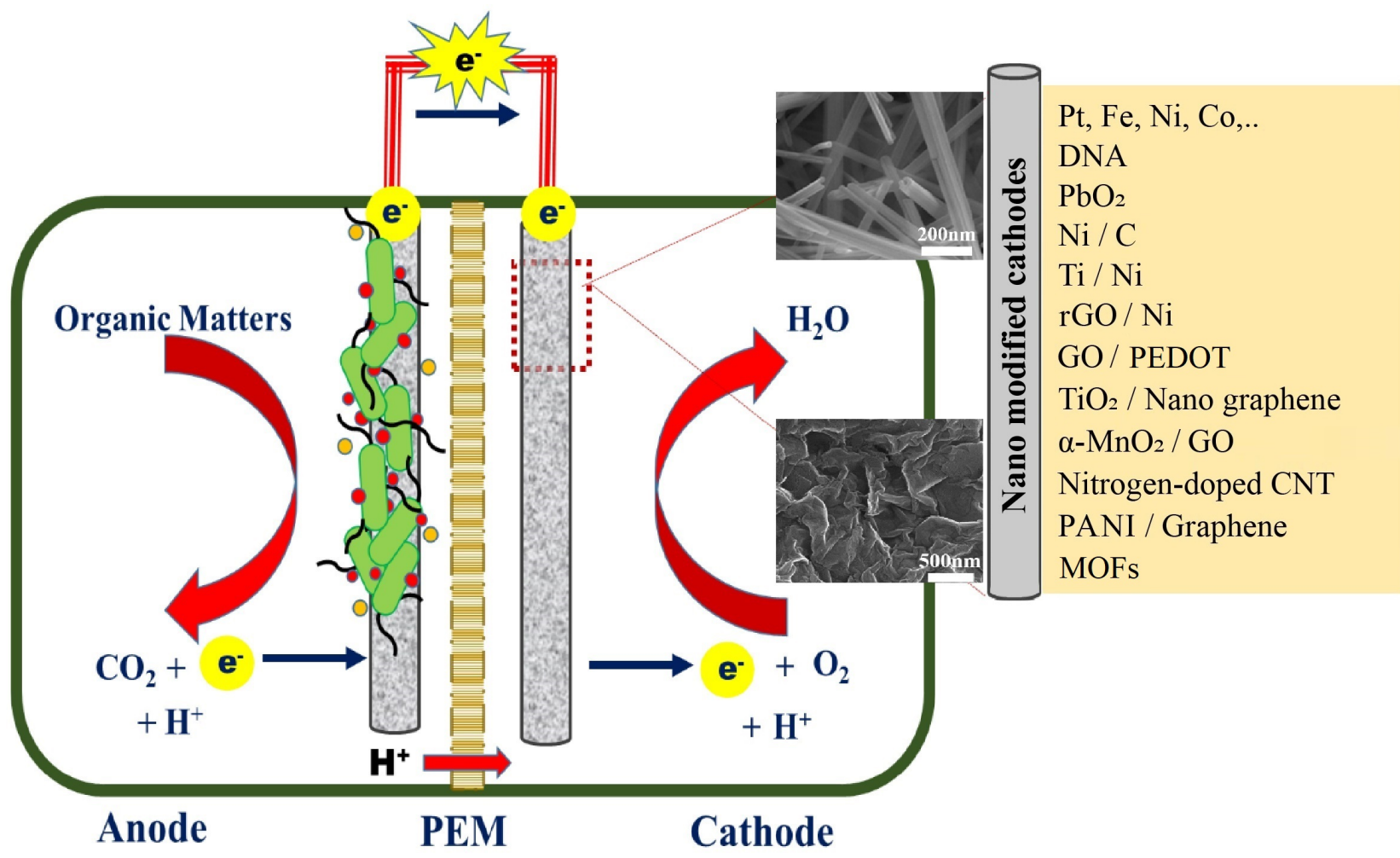

Shuttle molecule

Redox-active protein

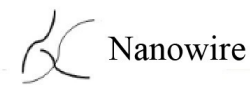

Electroactive microbe

Fig. 5. Application of nanomaterials for modifying MFC cathode surface.

density of $140 \mu \mathrm{W} / \mathrm{cm}^{2}$ vs. $0.6 \mu \mathrm{W} / \mathrm{m}^{2}$ recorded for bare carbon cloth. A $\mathrm{PANI} / \mathrm{MnO}_{2}$ nanocomposite was introduced by Ansari et al. (2016). Both metal oxide nanomaterials and conductive polymers are categorized as pseudocapacitors. Hence, the nanocomposite showed significant capacitance $(525 \mathrm{~F} / \mathrm{g})$ and $76.9 \%$ cycling stability for 1000 cycles. The maximum power density of $37.6 \mathrm{~mW} / \mathrm{m}^{2}$ was reported, which was considerably higher than the value recorded for carbon paper (approx. $0.003 \mathrm{~mW} / \mathrm{m}^{2}$ ). $\mathrm{TiO}_{2} \mathrm{NPs}$ were also utilized by Mashkour et al. (2017b) to modify a graphite-based cathode. The higher slope of the linear sweep voltammogram was indicative of the higher catalytic response of the modified cathode. This was reportedly also translated into a higher power density $\left(85 \mathrm{~mW} / \mathrm{m}^{2}\right)_{2}$ compared to $32 \mathrm{~mW} / \mathrm{m}^{2}$ recorded for the bare graphite (Mashkour et al., 2017b).

In addition to metal oxides nanomaterials, nitrogen-doped carbonous nanostructures have also been used to synthesize high-performance catalysts for cathode modification. The higher ratio of nitrogen to oxygen, obtained by the nitrogen doping process, is an effective ORR rate parameter. He et al. (2016) used nitrogen-doped CNT to modify carbon cloth cathode. The catalytic activity of the new composite electrode in ORR was higher than the Pt-coated carbon cloth. A maximum power density of $542 \mathrm{~mW} / \mathrm{m}^{3}$ was generated by the cathode, which was higher than that of the Pt coated one (approx. $500 \mathrm{~mW} / \mathrm{m}^{3}$ ) (He et al., 2016). In addition to nitrogen doping, phosphorus doping has also been reported by Liu et al. (2015) who performed a dual-doping procedure by in-situ pyrolysis of cellulose in the presence of ammonium phosphate as nitrogen and phosphorus source. They claimed remarkable enhancement in power density compared to the Pt coated cathode $\left(2293 \mathrm{~mW} / \mathrm{m}^{2}\right.$ vs. 1680 $\mathrm{mW} / \mathrm{m}^{2}$, respectively) (Liu et al., 2015) Cobalt is another choice for doping. Liu et al. (2016) and Zhong et al. (2021) synthesized cobalt-doped carbon mixtures showing comparable performance in terms of power density with their nitrogen-doped counterparts. Moreover, to develop nitrogen- and cobalt-doped carbonous nanostructures, metal organic frameworks (MOFs) have been used recently. For instance, Zhao et al. (2020) synthesized an ORR nanocatalyst by pyrolyzing a core-shell Co-MOF and adding rGO to the residue. The power density of the MFC equipped with the cathode modified by the MOF-based nanocatalyst increased to $2350 \mathrm{~mW} / \mathrm{m}^{2}$ vs. $2002 \mathrm{~mW} / \mathrm{m}^{2}$ measured for $\mathrm{Pt}$ (Zhao et al., 2020). In a different study, Zhong et al. (2019) introduced a Zr-based MOF as an excellent template for a nitrogen- and cobalt co-doped naocomposite ORR catalyst. They showed that the MOF-based catalyst could enhance MFC output (power density) to near the value reached by Pt-coated cathode $\left(300 \mathrm{~mW} / \mathrm{m}^{2} v s .313 \mathrm{~mW} / \mathrm{m}^{2}\right.$, respectively) (Zhong et al. 2019). Table 5 tabulates the results of several case studies investigating the application of nanomaterials in cathode modification on the performance (power density) of various MFC systems.

\section{- Application of nanomaterials for mitigating cathode biofouling}

Biofilm formation on the air-breathing cathode surface is a challenge in SCMFCs (Fig. 6a). The cathodic biofilm formed by anaerobic bacteria decreases the active sites of ORR on the cathode surface. So, hindering bacterial growth on air-cathode might be considered a solution in the longterm operation of MFCs. There are numerous efforts to mitigate the biofouling of air-cathode, including physical method, chemical cleaning, electrokinetic control, and surface modification (Al Lawati et al., 2019, Yang et al., 2019). Surface modification of air-cathodes using nanomaterials can also assist with mitigating this unfavorable phenomenon. Ma et al. (2015) used silver $(\mathrm{Ag})$ and iron oxide $\left(\mathrm{Fe}_{3} \mathrm{O}_{4}\right) \mathrm{NPs}$ in the carbon composite of the cathode and managed to control biofouling. They argued that the recovered power density after 17 cycles was about $96 \%$ of the initial value compared to $60 \%$ for the bare cathode. Similarly, Noori et al. (2018) also reported that the incorporation of silver in the catalyst layer of the composite helped recover $95 \%$ of the initial power density after 90 cycles. Both studies attributed the achievements made to the antibacterial properties of the silver NPs (AgNPs) (Yang et al., 2016; An et al., 2017). 
Table 5.

Effects of cathode modifications using nanomaterials on the performance (power density) of different MFC systems.

\begin{tabular}{|c|c|c|c|c|c|c|c|}
\hline \multirow{2}{*}{ Microorganism } & \multirow{2}{*}{ Device configuration } & \multirow{2}{*}{ Anode } & \multirow{2}{*}{$\begin{array}{l}\text { Cathode } \\
\text { (Control) }\end{array}$} & \multirow{2}{*}{$\begin{array}{l}\text { Cathode } \\
\text { (modified by nanomaterials) }\end{array}$} & \multicolumn{2}{|c|}{ Power density $\left(\mathbf{m A} / \mathbf{m}^{2}\right)$} & \multirow{2}{*}{ Reference } \\
\hline & & & & & Control & Modified & \\
\hline Mixed culture & $\begin{array}{l}\text { Double chamber } \\
\text { microbial fuel cell } \\
\text { (DCMFC) }\end{array}$ & Graphite & Carbon paper & $\begin{array}{l}\text { Pt/carbon nanotubes coated carbon } \\
\text { paper }\end{array}$ & 2.8 & 16.3 & $\begin{array}{l}\text { Mashkour and } \\
\text { Rahimnejad (2015) }\end{array}$ \\
\hline Escherichia coli & $\begin{array}{l}\text { Single chamber microbial } \\
\text { fuel cell (SCMFC) }\end{array}$ & Carbon cloth & Pt-coated carbon paper & $\begin{array}{l}\text { Carbon paper coated with } \mathrm{Co} / \mathrm{Ni} \\
\text { and nitrogen co-doped carbonous } \\
\text { nanoparticles }\end{array}$ & 2520 & 4336 & Tang et al. (2016) \\
\hline Mixed culture & SCMFC & Carbon brush & Pt-coated carbon cloth & $\begin{array}{l}\text { Reduced graphene oxide (rGO) } \\
\text { coated carbon cloth }\end{array}$ & 2021 & 1683 & Valipour et al. (2016) \\
\hline Mixed culture & DCMFC & Graphite & Graphite paste & $\begin{array}{l}\text { Hybrid graphene-modified } \\
\text { graphite paste }\end{array}$ & 30 & 220 & Mashkour et al. (2017b) \\
\hline Mixed culture & SCMFC & Carbon brush & $\begin{array}{l}\text { Activated carbon-Carbon } \\
\text { black (AC-CB) based }\end{array}$ & $\begin{array}{l}\text { Iron aminoantipyrine-graphene } \\
\text { nanosheet modified AC-CB }\end{array}$ & 1030 & 2030 & Kodali et al. (2018) \\
\hline Mixed culture & SCMFC & Graphite felt & $\begin{array}{l}\text { Carbon paper coated with } \\
\text { Cu-based metal organic } \\
\text { framework (MOF) }\end{array}$ & $\begin{array}{l}\text { Carbon paper coated with } \\
\text { pyrolyzed } \mathrm{Cu} \text {-based MOF }\end{array}$ & 126 & 326 & Zhang et al. (2018c) \\
\hline Mixed culture & SCMFC & Carbon cloth & Pt-coated carbon cloth & $\begin{array}{l}\text { Nickel-nickel oxide-polypyrrol- } \\
\text { rGO coated carbon cloth }\end{array}$ & 481 & 678 & Pattanayak et al. (2019) \\
\hline Mixed culture & SCMFC & Carbon felt & Activated carbon & $\begin{array}{l}\text { Pyrolised } \mathrm{ZnCo} \mathrm{zeolitic} \\
\text { imidazolate framework }\end{array}$ & 2252 & 888 & Zhang et al. (2019) \\
\hline Mixed culture & SCMFC & Carbon cloth & Pt-coated carbon cloth & GO-Zn/CoO coated carbon cloth & 744 & 773 & Yang et al. (2019) \\
\hline Mixed culture & SCMFC & Graphite felt & Stainless steel (SS) based & $\begin{array}{l}\mathrm{NiFe} \text { layered double hydroxide- } \\
\mathrm{Co}_{3} \mathrm{O}_{4} \text { modified SS }\end{array}$ & 6.25 & 467 & Jiang et al. (2020) \\
\hline Mixed culture & SCMFC & Carbon felt & Pt-coated carbon felt & $\begin{array}{l}\mathrm{Ni} \text {-sheathed } \mathrm{NiO}_{\mathrm{x}} \text { nanoparticle } \\
\text { coated carbon felt }\end{array}$ & 489 & 1630 & Choi et al. (2020) \\
\hline Mixed culture & SCMFC & - & Carbon felt & $\begin{array}{l}\mathrm{SnO}_{2} \text {-polyaniline modified carbon } \\
\text { felt }\end{array}$ & $200 \%$ i & ovement* & Tiwari et al. (2020) \\
\hline- & SCMFC & Carbon felt & Pt-coated carbon cloth & Pyrolyzed $\mathrm{gC}_{3} \mathrm{~N}_{4}-\mathrm{MOF}$ & 126 & 136 & Wang et al. (2020) \\
\hline Mixed culture & SCMFC & Carbon felt & Activated carbon based & $\begin{array}{l}\text { Co/Nitrogen-doped carbon-carbon } \\
\text { nanotubes modified AC }\end{array}$ & 714 & 2479 & Zhong et al. (2021) \\
\hline
\end{tabular}

* Only variations in power density $(\%)$ were reported in some studies.
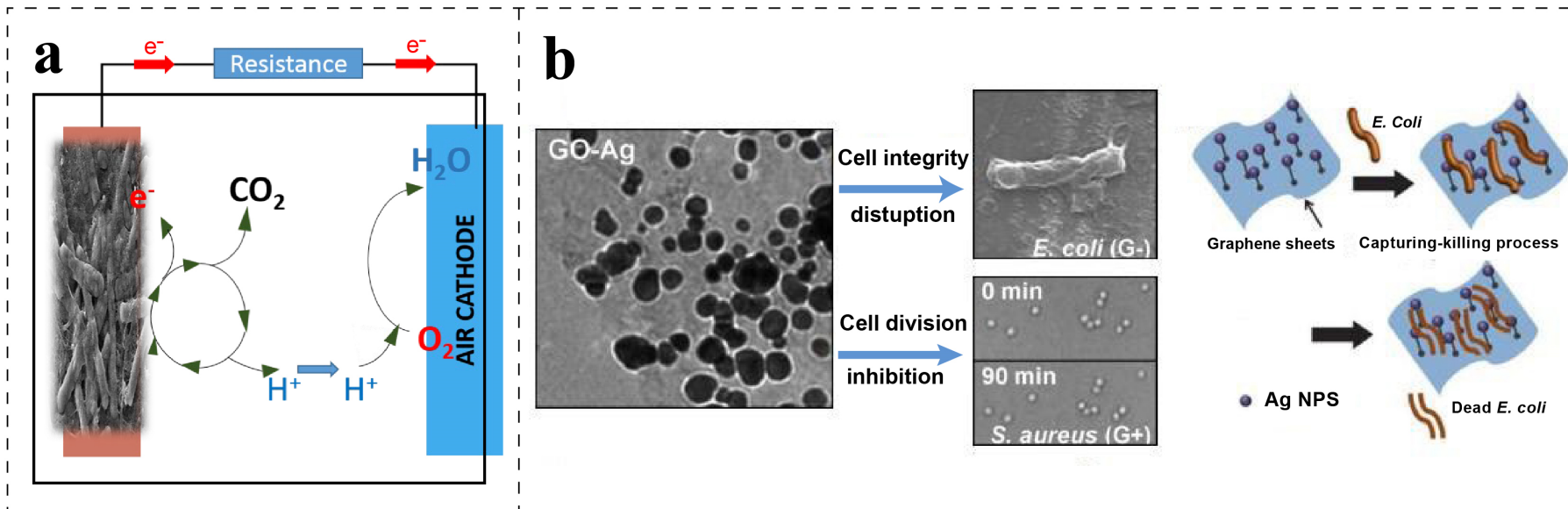

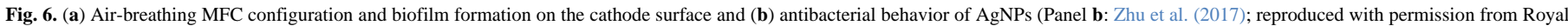
Society of Chemistry. Copyright $\odot 2017$. License No. 1113216-1.).

Please cite this article as: Mashkour M., Rahimnejad M., Raouf F., Navidjouy N. A review on the application of nanomaterials in improving microbial fuel cells. Biofuel Research Journal 30 (2021) 1400-1416. DOI: 10.18331/BRJ2021.8.2.5 
Figure $6 \mathrm{~b}$ depicts the effect of AgNPs-coated GO on gram-negative and gram-positive bacteria (Zhu et al., 2017). ZnONPs and CoNPs with antimicrobial properties were also applied to fabricate the catalyst layer of aircathodes (Yang et al., 2019). By decreasing cathode biofouling, less power density drop was recorded after 30 cycles than for Pt catalyst as control.

\subsection{Application of nanomaterials in MFC membranes}

Membranes are among the main factors affecting the performance of MFCs. Proton exchange membranes (PEMs) transfer protons from the anode to the cathode, prevent substrate leakage from the anode to the cathode, and stops oxygen cross-over between the cathode and the anode (Shabani et al., 2020). In MFCs, typical commercial membranes, including Ultrex and Nafion, are generally used (San-Martín et al., 2019). However, these membranes suffer from several disadvantages, including high prices (e.g., $1500 \mathrm{USD} / \mathrm{m}^{2}$ for Nafion 115), biofouling, and oxygen and substrate cross-over (Dizge et al., 2019; Palanisamy et al., 2019). The disadvantages of the commercial membranes have motivated the synthesis of diverse materials, particularly in their nano-sized forms, and their incorporation into membrane structures to address the mentioned challenges. Figure 7 shows the MFC membranes, which could be modified using nanomaterials. Table 6 tabulates the results of several case studies investigating the application of nanomaterials in membrane modification on the performance (power density) of various MFC systems.

Bazrgar Bajestani and Mousavi (2016) modified a conventional Nafion using $\mathrm{TiO}_{2}$ NPs. The formation of $\mathrm{Ti}-\mathrm{OH}$ groups in the $\mathrm{TiO}_{2}$-based nanocomposite membrane increased the exchange sites over the membrane, leading to higher ion conductivity than Nafion. The nanocomposite could also provide a higher water uptake comparatively (Bazrgar Bajestani and Mousavi, 2016). Sulfonated $\mathrm{TiO}_{2}\left(\mathrm{sTiO}_{2}\right)$ NPs were also reported as a modifier for sulfonated polystyrene ethylene butylene polystyrene (SPSEBS). The nanocomposite membrane showed higher proton conductivity, much lower

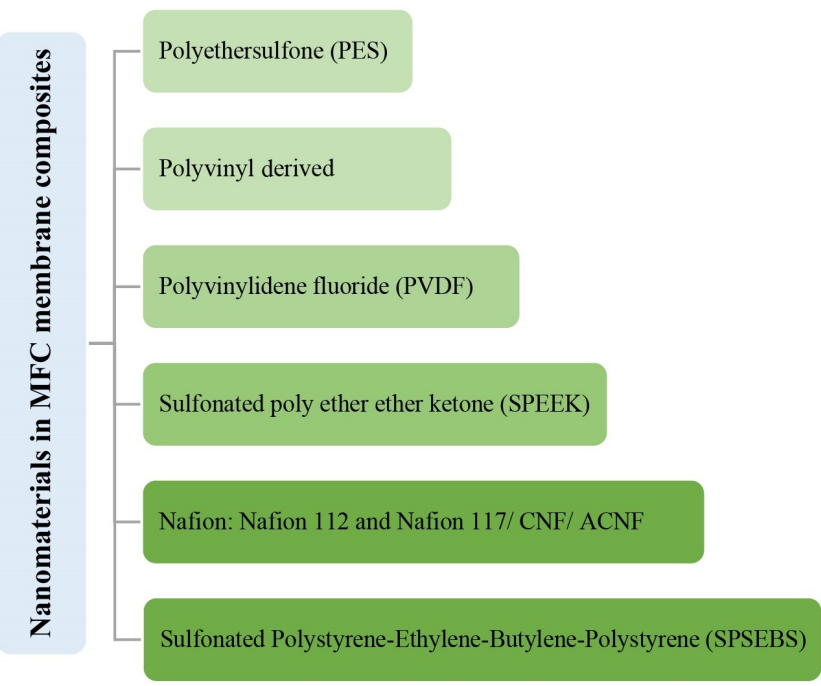

Fig. 7. Various microbial fuel cell (MFC) membranes which could be modified using nanomaterials.

oxygen cross-over, and much lower cost $\left(200 \mathrm{USD} / \mathrm{m}^{2}\right)$ than commercial Nafion 117 (Ayyaru and Dharmalingam, 2015). Due to the mentioned improved features, power density and coulombic efficiency of the MFC with the $\mathrm{sTiO}_{2}$-SPSEBS membrane increased.

Table 6.

Effects of membrane modifications using nanomaterials on the performance (power density) of different MFC systems.

\begin{tabular}{|c|c|c|c|c|c|c|c|c|}
\hline \multirow{2}{*}{ Device configuration } & \multirow{2}{*}{ Anode } & \multirow{2}{*}{ Cathode } & \multirow{2}{*}{ Microorganism } & \multirow{2}{*}{ Membrane (Control) } & \multirow{2}{*}{$\begin{array}{l}\text { Membrane (modified } \\
\text { by nanomaterials) }\end{array}$} & \multicolumn{2}{|c|}{$\begin{array}{l}\text { Power density } \\
\left(\mathbf{m W} / \mathbf{m}^{2}\right)\end{array}$} & \multirow{2}{*}{ Reference } \\
\hline & & & & & & Control & Modified & \\
\hline $\begin{array}{l}\text { Double chamber } \\
\text { microbial fuel cell } \\
\text { (DCMFC) }\end{array}$ & Carbon paper & $\begin{array}{l}\text { Pt-coated carbon } \\
\text { paper }\end{array}$ & Mixed culture & $\begin{array}{l}\text { Sulfonated polyether ether } \\
\text { ketone (SPEEK) }\end{array}$ & $\begin{array}{l}\text { Graphene oxide (GO) } \\
\text { modified SPEEK }\end{array}$ & 812 & 902 & Leong et al. (2015) \\
\hline $\begin{array}{l}\text { Single chamber } \\
\text { microbial fuel cell } \\
\text { (SCMFC) }\end{array}$ & Carbon cloth & $\begin{array}{l}\text { Pt-coated carbon } \\
\text { cloth }\end{array}$ & Mixed culture & SPEEK & SPEEK-SiO ${ }_{2}$ & 680.0 & 802.0 & $\begin{array}{l}\text { Sivasankaran and } \\
\text { Sangeetha (2015) }\end{array}$ \\
\hline SCMFC & $\begin{array}{c}\text { Carbon } \\
\text { cloth/Carbon } \\
\text { vulcan }\end{array}$ & $\begin{array}{l}\text { Pt-coated Carbon } \\
\text { cloth/Carbon } \\
\text { vulcan }\end{array}$ & Mixed culture & $\begin{array}{l}\text { Quaternized polysulphone } \\
\text { (QPSU) }\end{array}$ & GO modified QPSU & 800 & 1050 & $\begin{array}{l}\text { Elangovan and } \\
\text { Dharmalingam } \\
(2016)\end{array}$ \\
\hline DCMFC & Carbon rod & Carbon rod & Mixed culture & $\begin{array}{c}\text { Phosphoric acid-treated } \\
\text { chitosan }\end{array}$ & $\begin{array}{l}\text { Phosphoric acid-treated } \\
\text { chitosan-GO }\end{array}$ & 0.25 & 3.87 & Holder et al. (2017) \\
\hline DCMFC & Carbon paper & Carbon paper & Mixed culture & Polyethersulfone (PES) & $\begin{array}{l}\mathrm{Fe}_{3} \mathrm{O}_{4} \text { nanoparticles } \\
\text { modified PES }\end{array}$ & 0.1 & 9.6 & $\begin{array}{l}\text { Di Palma et al. } \\
\text { (2018) }\end{array}$ \\
\hline DCMFC & Carbon felt & Carbon felt & Mixed culture & $\begin{array}{l}\text { poly(-vinylidene fluoride) } \\
\text { grafted sodium styrene } \\
\text { sulfonate (PVDF-g-PSSA) }\end{array}$ & $\begin{array}{l}\text { Sulphonated GO-SiO } \\
\text { modified PVDF-g-PSSA }\end{array}$ & 147 & 185 & Xu et al. (2019) \\
\hline DCMFC & Carbon paper & $\begin{array}{l}\text { Pt-coated carbon } \\
\text { paper }\end{array}$ & Mixed culture & Nafion 117 & $\begin{array}{l}\text { Ag-GO modified GO- } \\
\text { SPEEK }\end{array}$ & 1013 & 1049 & Liew et al. (2020) \\
\hline SCMFC & Graphite rod & Carbon cloth & Mixed culture & SPEEK & $\begin{array}{l}\text { Sulphonated titanium } \\
\text { nanotubes modified } \\
\text { SPEEK }\end{array}$ & 59 & 121 & $\begin{array}{l}\text { Kugarajah and } \\
\text { Dharmalingam } \\
\text { (2020) }\end{array}$ \\
\hline SCMFC & Graphite rod & Carbon cloth & Mixed culture & SPEEK & SPEEK-Ag nanoparticles & 60 & 160 & $\begin{array}{l}\text { Kugarajah and } \\
\text { Dharmalingam } \\
(2021)\end{array}$ \\
\hline SCMFC & Carbon brush & - & Mixed culture & $\begin{array}{l}\text { No membrane (Carbon } \\
\text { cloth-PTFE air-cathode) }\end{array}$ & $\begin{array}{l}\text { Nano-zycosil treated } \\
\text { bacterial cellulose-carbon } \\
\text { nanotubes }\end{array}$ & 920 & 1790 & $\begin{array}{l}\text { Mashkour et al. } \\
\text { (2021) }\end{array}$ \\
\hline
\end{tabular}

* Polyvinylidene fluoride

Please cite this article as: Mashkour M., Rahimnejad M., Raouf F., Navidjouy N. A review on the application of nanomaterials in improving microbial fuel cells. Biofuel Research Journal 30 (2021) 1400-1416. DOI: 10.18331/BRJ2021.8.2.5 
Sulfonated poly(ether ether ketone) (SPEEK) is also a typical polymer used to synthesize nanocomposite membranes for MFCs and is a low-cost polymer compared to Nafion. A nanocomposite made by SPEEK and sulfonated $\mathrm{SiO}_{2}$ has been reported as a PEM for an SCMFC (Sivasankaran and Sangeetha, 2015). The $\mathrm{SiO}_{2}$-modified membrane had an increased water uptake and proton conductivity compared to the bare SPEEK. Also, as a low-cost membrane, it showed much higher power density than Nafion 115. Moreover, the nanocomposite membrane showed a lower oxygen mass transfer coefficient and reduced substrate leakage. The high performance of the SPEEK nanocomposite was obtained using $7.5 \% \mathrm{SiO}_{2}$ in the polymer matrix (Sivasankaran and Sangeetha, 2015). For improving SPEEK, Shabani et al. (2019) suggested adding GO nanosheets to the SPEEK mixture during synthesis. They claimed that oxygen cross-over of the nanocomposite membrane was about $50 \%$ lower than that of Nafion 117 while its conductivity was $25 \%$ higher

Contrary to the favorable results obtained using $\mathrm{TiO}_{2}$ and $\mathrm{SiO}_{2} \mathrm{NPs}$ in nanocomposite membranes, using $\mathrm{Fe}_{3} \mathrm{O}_{4}$ NPs in a polyethersulfone (PES) matrix led to lower performance than Nafion, i.e., lower conductivity and higher oxygen cross-over (Di Palma et al., 2018). Moreover, increasing the NPs content in the nanocomposite resulted in reduced water uptake and increased oxygen transfer coefficient owing to the lack of sulfonated NPs and increased void space in the matrix, respectively. Therefore, the adverse effects associated with using nanocomposite membranes in MFCs should also be considered by future studies.

Ceramic membranes are also used in MFCs owing to their low cost. Ahilan et al. (2019) synthesized a polysiloxane-derived ceramic nanocomposite membrane with MWCNTs and GO and compared them with Nafion as control. The maximum power density obtained using the investigated membranes was in the following order: GO-modified membrane > Nafion > MWCNTsmodified membrane. However, the fresh nanomaterial-modified ceramic membranes showed less ion conductivity and higher oxygen cross-over than the Nafion (Ahilan et al., 2019). Nevertheless, it should be emphasized that the ion conductivity of the modified membrane might be sustained throughout time, whereas that of Nafion's is likely to diminish due to biofouling.

In addition to membrane composition, membrane electrode assembly (MEA) is also of great importance for the performance of SCMFCs. Nanocellulosic materials, by providing 3D nanoporous structures (Mashkour et al., 2018), are among the most exciting substrates for fabricating MEAs. In a recent investigation, a BC-based MEA was reported to outperform a carbon cloth-based gas diffusion electrode (GDE) (Mashkour et al., 2021). In this study, one side of the BC was coated with MWCNTs for ORR. In contrast, the other side was coated by the hydrophobic nano-zycosil (NZ) to moderate the highly hydrophilic nature of the BC. This strategy would assist with achieving a favorable proton transfer driven by the hydrophilic nature of the $\mathrm{BC}$ and mitigating substrate leakage caused by the hydrophobic nature of NZ (Fig. 8). Interestingly, despite the existing BC membrane resistance, the cell's internal resistance with BC MEA was lower than that of the cell harboring the carbon cloth-based GDE (Mashkour et al., 2021).

This phenomenon could be attributed to the high conductivity of MWCNTs, homogeneous coating, and excellent behavior of NZ as a lowcost hydrophobic agent. Also, oxygen cross-over was lower in the BC MEA than the carbon cloth-based GDE, which could be explained by the barrier properties of nano cellulosic fibers (Aulin et al., 2010).

\section{Improved MFC applications through nanomaterial-based modification}

The improvements achieved in MFC applications through modifying its different compartments by nanomaterials are presented and discussed in this section. Electricity generation is excluded, as was discussed previously.

\subsection{Wastewater treatment}

MFC, as a biological wastewater treatment system, has a high theoretical energy conversion rate and produces less sludge than other treatment technologies. The elimination of various types of compounds, including heavy metals (Cr (VI), Cu (II), Zn (II)), azo dyes, and nutrients, has been reported by MFC technology (Feng et al., 2017). MFCs can also eliminate nitrogen and phosphorous-based compounds in their biocathode chambers. Figure 9 depicts the application of MFCs for the elimination of various sources of pollution. Despite the beneficial characteristics of MFCs, they need to be enhanced (in terms of power output and wastewater treatment capacity) to outcompete the traditional wastewater treatment procedures (Ci et al., 2017; Salar-García and Ortiz-Martínez, 2019). Applying efficient advanced materials such as nanomaterials is widely regarded as a strategy to achieve this objective (Kim et al., 2016; Feng et al., 2017; Salar-García and Ortiz-Martínez, 2019).

Nanomaterials have multiple functions, including enhancing the separator's selectivity, improving catalyst activity, decreasing oxygen cross-over, improving the growth of anodic biofilm (Munoz-Cupa et al., 2020). It should be highlighted that anodic biofilm activity in MFCs is critical for chemical oxygen demand (COD) removal. Using a high-
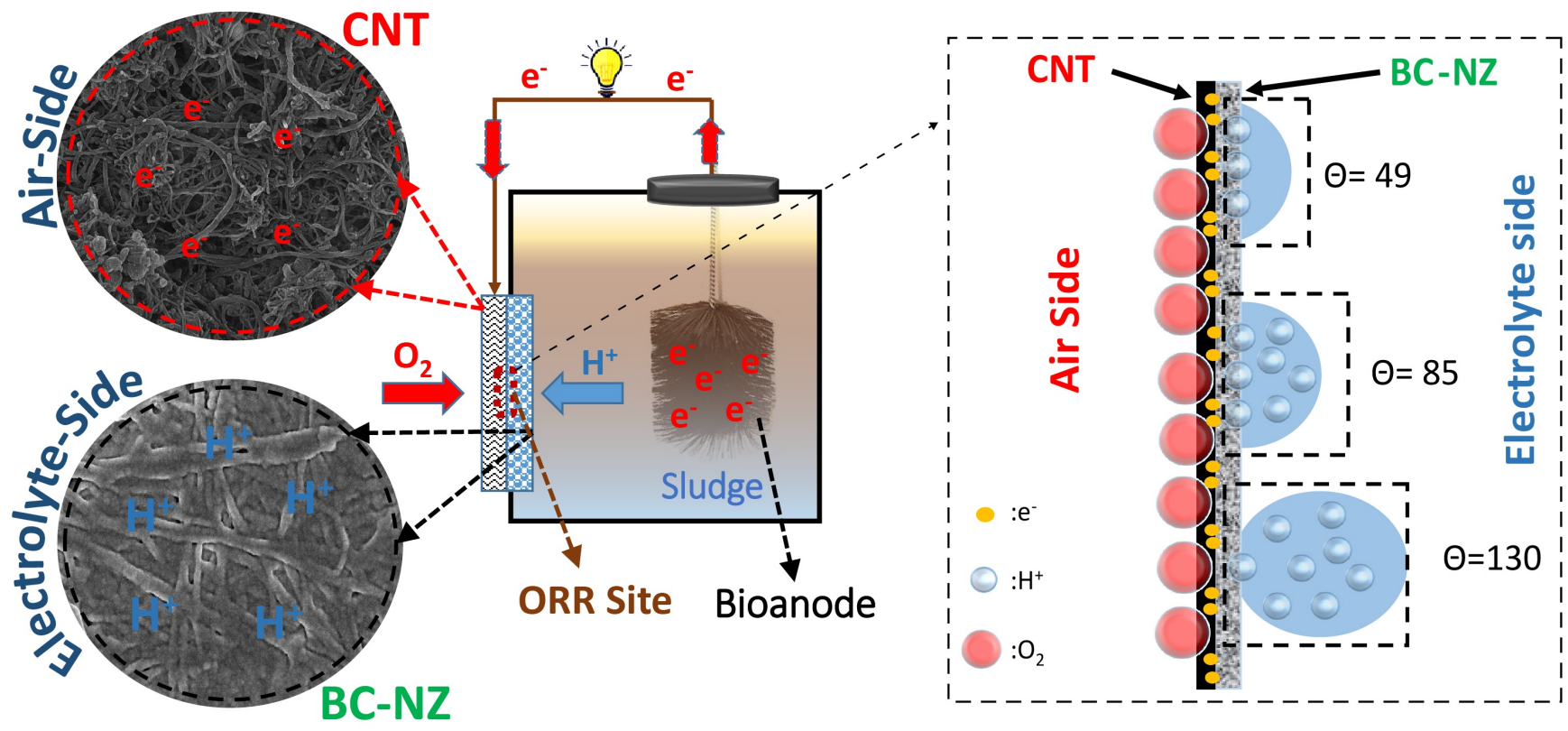

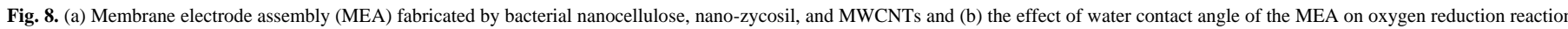
(ORR) (Mashkour et al., 2021). With permission from Elsevier. Copyright@2021. License No.: 5052280823847. 


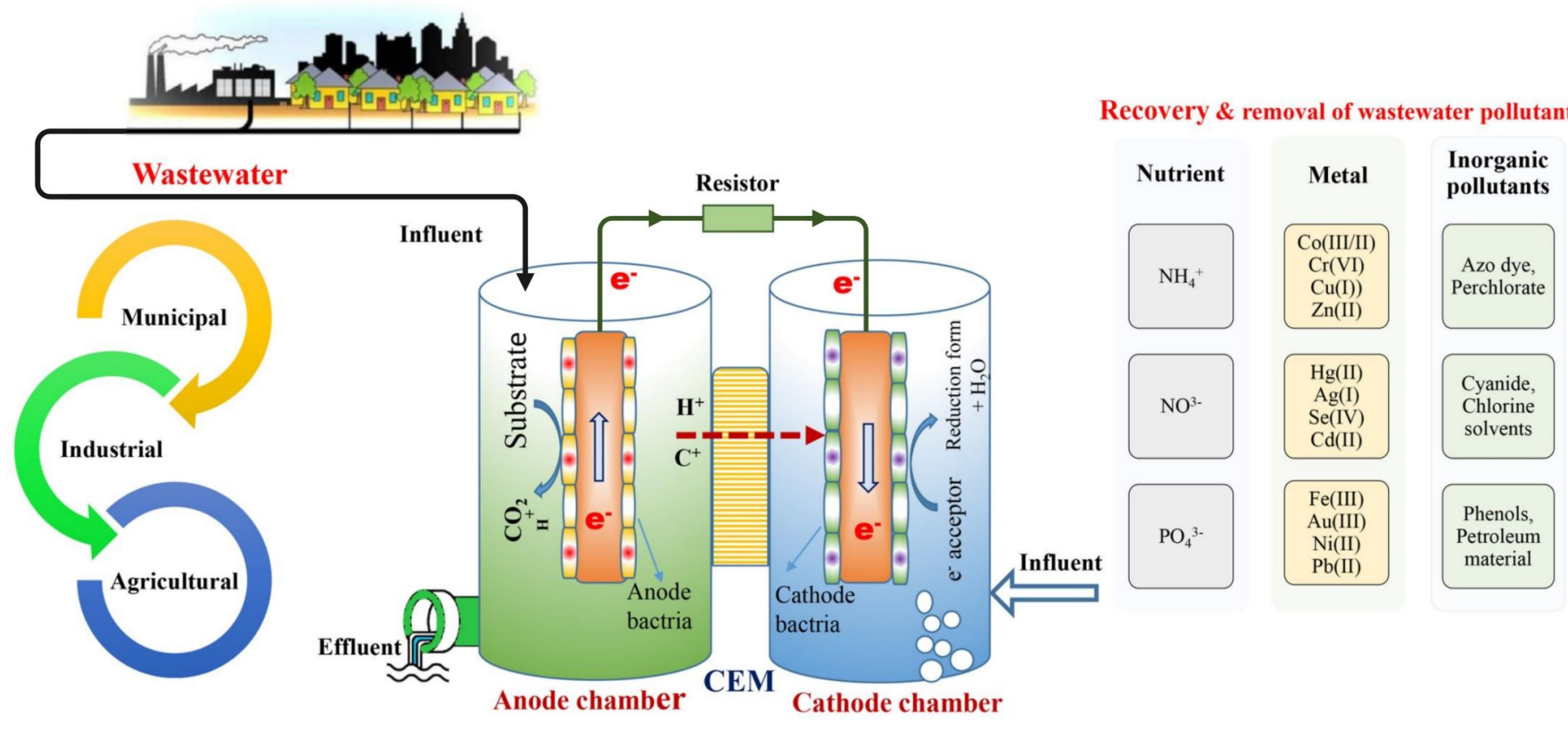

Fig. 9. Potential applications of microbial fuel cells (MFCs) for eliminating various sources of pollution and power generation.

performance membrane modified by nanomaterials could offer a low oxygen cross-over, providing a stable anaerobic condition for microbial activity. High surface area and high prosity of nanomaterial-based electrodes can accelerate the adsorption process of toxic compounds and increase bacterial colonization, resulting in higher treatment rates. Cathode modifications using nanomaterials could lead to higher surface areas and redox activities. Such an enhanced cathode could assist with controlling neutral conditions in the anode chamber by reducing proton accumulation in the anolyte.

\subsection{Self-powered nanobiosensing}

One of the essential applications of MFCs is detecting the quality of wastewater as self-powered biosensors. The high sensitivity of microbes to a different spectrum of analytes makes MFCs capable of being used as highperformance biosensors. MFCs can be utilized as biological oxygen demand (BOD), dissolved oxygen, volatile fatty acid, organic carbon, toxicity, and microbial activity measurement device (Ivars-Barceló et al., 2018; Cui et al.,
2019). A noticeable feature of MFC-based biosensors is that no transducers are required for reading and converting the signal. However, their applications have been limited by low sensitivity, low stability, long response time, and irreproducibility (Chen et al., 2019; Do et al., 2020). Electrode improvements might be a valuable and essential solution for enhancing the performance of MFC-based biosensors. In recent years, the detection resolution of MFC biosensors has increased using nanomaterials in electrode surface modifications. A considerable range of nanomaterials, including carbon NPs, AuNPs, PEDOT:PSS conductive polymer, and $\mathrm{CoMn}_{2} \mathrm{O}_{4}$ NPs, have been utilized in enhancing MFC-based biosensors, as tabulated in Table 7.

To better understand nanomaterials' effect on the performance of MFCbased nanobiosensors, it is vital to know the sensing mechanism. For example, for toxicity determination, the anode is the active point of the MFC sensor, while for detecting $\mathrm{H}_{2} \mathrm{O}_{2}$, the cathode is the active point. Also, having a higher voltage and current range in MFCs may lead to the system's higher sensitivity. Therefore, nanomaterials, through boosting the

Table 7.

Use of nanomaterials for fabricating MFC-based nanobiosensors.

\begin{tabular}{|c|c|c|c|c|c|}
\hline Analyte & Device configuration & Anode & Nanomaterial-modified Cathode & Reported features & Reference \\
\hline DNA & DCMFC & Graphite plate & AuNPs/graphite & $\begin{array}{l}\text { Range of detection: } 0.0-0.1 \mathrm{mM} \\
\text { Limit of detection: } 3.1 \mathrm{nM} \text { LOD }\end{array}$ & Asghary et al. (2016) \\
\hline BOD & SCMFC & Carbon cloth & Carbon cloth with $\mathrm{MnO}_{2}$ NPs and CNTs & $\begin{array}{l}\text { Range of detection: } 50-100 \mathrm{mg} / \mathrm{L} \\
\text { Stability: } 1.5 \mathrm{yr}\end{array}$ & Kharkwal et al. (2017) \\
\hline Levofloxacin & SCMFC & Microbial & $\mathrm{FePO}_{4}$ nanoparticles & $\begin{array}{l}\text { Range of detection: } 0.1-100 \mu \mathrm{g} / \mathrm{L} \\
\text { Limit of detection: } 0.1 \mu \mathrm{g} / \mathrm{L}\end{array}$ & Zeng et al. (2017) \\
\hline $\mathrm{H}_{2} \mathrm{O}_{2}$ & DCMFC & Microorganism & $\mathrm{CoMn}_{2} \mathrm{O}_{4} /$ graphite & $\begin{array}{l}\text { Range of detection: } 1-1000 \mathrm{mM} \\
\text { Limit of detection: } 40.2 \mu \mathrm{M}\end{array}$ & Liu et al. (2018) \\
\hline Formaldehyde & Screen printed MFC & $\begin{array}{l}\text { Carbon nanofiber modified } \\
\alpha \text {-cellulose paper }\end{array}$ & $\begin{array}{l}\text { Carbon nanofiber modified } \alpha \text {-cellulose } \\
\text { paper }\end{array}$ & $\begin{array}{l}\text { Detecting the analyte at } 0.1 \% \\
\text { concentration only }\end{array}$ & Chouler et al. (2018) \\
\hline Formaldehyde & Dry DCMFC & Cellulose-PEDOT:PSS & Cellulose- $\mathrm{Ag}_{2} \mathrm{O}$ PEDOT:PSS & Range of detection: $0.001 \%-0.2 \%$ & Cho et al. (2019) \\
\hline BOD & SCMFC & Graphite rode & Carbon paper with carbon nanoparticles & Range of detection: $32-1280 \mathrm{mg} / \mathrm{L}$ & Do et al. (2020) \\
\hline BOD & micro-DCMFC & CNT-treated carbon cloth & - & Range of detection: $0.1-0.7 \mathrm{~g} / \mathrm{L}$ & Xiao et al. (2020) \\
\hline
\end{tabular}

Please cite this article as: Mashkour M., Rahimnejad M., Raouf F., Navidjouy N. A review on the application of nanomaterials in improving microbial fuel cells. Biofuel Research Journal 30 (2021) 1400-1416. DOI: 10.18331/BRJ2021.8.2.5 


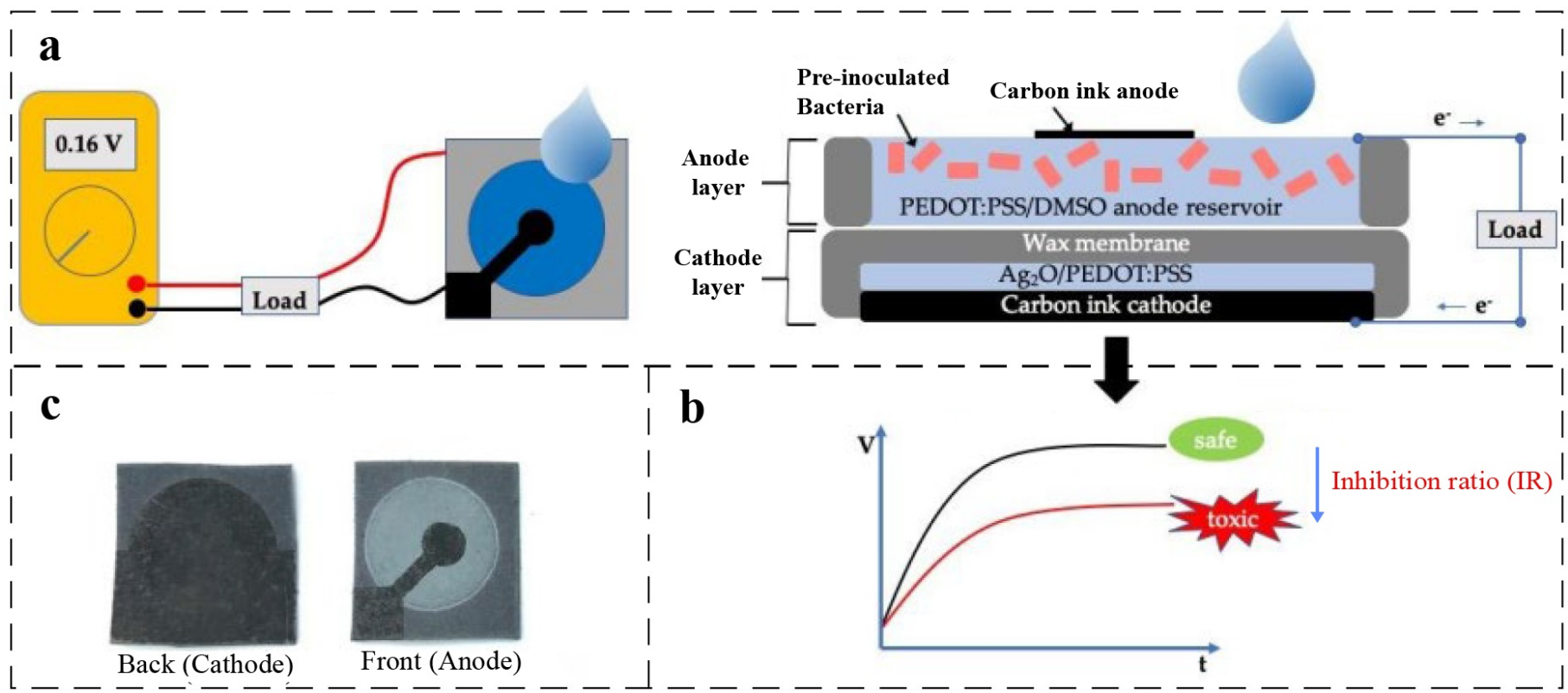

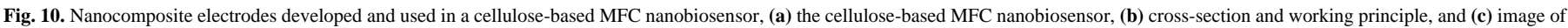
the front and back sides of the MFC nanobionsensor (Cho et al., 2019). Reproduced with permission from MDPI.

performance of different MFC compartments could result in increased biosensing performance.

Among various nanomaterials used in MFC modifications, cellulosic nanomaterials and their application in fabricating cellulose-based electrodes have attracted a great deal of attention. This is ascribed to the fact that these modified electrodes can decrease the costs of MFC-based nanobiosensors. A paper-based water quality biosensor based on MFC's anodic activity was recently introduced for detecting formaldehyde in water (Cho et al., 2019). As shown in Figure 10, in the developed system, two layers of PEDOT:PSS modified paper were used as anode and cathode. PEDOT:PSS nano-coating made the surface of the cellulose-based anode more biocompatible, facilitating bacterial colonization. Moreover, the modified anode could absorb water more quickly, further enhancing microbial growth. Nano-coated electrodes were also more conductive, decreasing the time needed for the MFC to reach a stable voltage for starting the detection process (Cho et al., 2019).

\section{Concluding remarks and future research directions}

Nanotechnology offers extensive possibilities for MFC improvements. In this review, the applications of nanomaterials in different MFC compartments were reviewed and discussed in detail. The following main conclusions could be drawn from the reviewed literature:

- High-surface-area/biocompatible nanomaterials are instrumentals in developing thick biofilms on electrodes' surface.

- Conductive NPs act as bridges between the biofilm and electrode surface and decrease electron transfer resistance. However, more investigation on the effect of nanoparticle morphology on electron transfer is still needed.

- Toxicity of CNTs to microbial biofilms would depend on CNTs' concentration. Also, the adverse effects associated with electrode modifications using CNTs could be moderated by adding biocompatible nanomaterials such as PANI.

- Nanoporous materials increase cathodic gas adsorption, leading to increased microbial electrosynthesis of chemicals.

- Metal oxide- and MOF-based nanocomposites can efficiently catalyze the ORR and are considered inexpensive alternatives to Pt. They are also higher more stable in microbial environments.

- Nitrogen- and metal-doping can extend ORR active sites of carbonous nanomaterials.
- Inexpensive and high-performance alternatives to conventional PEMs could be obtained by modifying polymeric membranes with hydrophilic and antimicrobial NPs. The modified membranes are also less prone to biofouling.

- High-performance electrodes and membranes can be achieved by modifyng $\mathrm{BC}$ with nanomaterials.

Nanomaterials have vastly improved MFC applications in wastewater treatment and biosensing. However, for a stable and reproducible response, MFCs should still be further improved. The unknown environmental impacts of nanomaterials used in MFC modification, caused by their release into soil and water, are considered a significant challenge to the overall sustainability of the whole technology. Hence, future research efforts should also take into account the human and environmental safety features of nanomaterial-modified MFCs.

\section{Acknowledgments}

This work was supported by Iran National Science Foundation (INSF), grant number: INSF-95819857, Babol Noshirvani University and Technology (BNUT) (Grant number: BNUT/5150010/1394), and by Erasmus Project: 585596-EPP-1-2017-1-DE-EPPKA2-CBHE- JP. The authors would like to acknowledge the support provided by the Biofuel \& Renewable Energy Research Center at BNUT and Danesh Gostar Hamgam Ba Sanat Co.

\section{References}

[1] Ahilan, V., de Barros, C.C., Bhowmick, G.D., Ghangrekar, M.M., Murshed, M.M., Wilhelm, M., Rezwan, K., 2019. Microbial fuel cell performance of graphitic carbon functionalized porous polysiloxane based ceramic membranes. Bioelectrochemistry. 129, 259-269.

[2] Al Lawati, M.J., Jafary, T., Baawain, M.S., Al-Mamun, A., 2019. A mini review on biofouling on air cathode of single chamber microbial fuel cell; prevention and mitigation strategies. Biocatal. Agric. Biotechnol. 22, 101370

[3] An, J., Li, N., Wan, L., Zhou, L., Du, Q., Li, T., Wang, X., 2017. Electric field induced salt precipitation into activated carbon aircathode causes power decay in microbial fuel cells. Water Res. 123, 369-377. 
[4] Ansari, S.A., Parveen, N., Han, T.H., Ansari, M.O., Cho, M.H., 2016. Fibrous polyaniline@ manganese oxide nanocomposites as supercapacitor electrode materials and cathode catalysts for improved power production in microbial fuel cells. Phys. Chem. Chem. Phys. 18(13), 9053-9060

[5] Anwer, A., Khan, M., Khan, N., Nizami, A., Rehan, M., Khan, M., 2019. Development of novel $\mathrm{MnO}_{2}$ coated carbon felt cathode for microbial electroreduction of CO2 to biofuels. J. Environ. Manage. 249, 109376.

[6] Aryal, N., Halder, A., Zhang, M., Whelan, P.R., Tremblay, P.L., Chi, Q., Zhang, T., 2017. Freestanding and flexible graphene papers as bioelectrochemical cathode for selective and efficient $\mathrm{CO}_{2}$ conversion. Sci. Rep. 7(1), 1-8.

[7] Aryal, N., Wan, L., Overgaard, M.H., Stoot, A.C., Chen, Y., Tremblay, P.L., Zhang, T., 2019. Increased carbon dioxide reduction to acetate in a microbial electrosynthesis reactor with a reduced graphene oxide-coated copper foam composite cathode. Bioelectrochemistry. 128, 83-93.

[8] Asghary, M., Raoof, J.B., Rahimnejad, M., Ojani, R., 2016. A novel selfpowered and sensitive label-free DNA biosensor in microbial fuel cell. Biosens. Bioelectron. 82, 173-176.

[9] Aulin, C., Gällstedt, M., Lindström, T., 2010. Oxygen and oil barrier properties of microfibrillated cellulose films and coatings. Cellulose. 17(3), 559-574

[10] Ayyaru, S., Dharmalingam, S., 2015. A study of influence on nanocomposite membrane of sulfonated $\mathrm{TiO}_{2}$ and sulfonated polystyrene-ethylene-butylene-polystyrene for microbial fuel cell application. Energy. 88, 202-208.

[11] Bazrgar Bajestani, M., Mousavi, S.A., 2016. Effect of casting solvent on the characteristics of $\mathrm{Nafion} / \mathrm{TiO}_{2}$ nanocomposite membranes for microbial fuel cell application. Int. J. Hydrogen Energy. 41(1), 476-482.

[12] Berchmans, S., 2018. Microbial fuel cell as alternate power tool: potential and challenges. Microbial Fuel Cell. Springer, pp. 403-419.

[13] Bian, B., Alqahtani, M.F., Katuri, K.P., Liu, D., Bajracharya, S., Lai, Z., Rabaey, K., Saikaly, P.E., 2018. Porous nickel hollow fiber cathodes coated with CNTs for efficient microbial electrosynthesis of acetate from $\mathrm{CO}_{2}$ using Sporomusa ovata. J. Mater. Chem. A. 6(35), 17201-17211.

[14] Cai, T., Meng, L., Chen, G., Xi, Y., Jiang, N., Song, J., Zheng, S., Liu, Y., Zhen, G., Huang, M., 2020a. Application of advanced anodes in microbial fuel cells for power generation: A review. Chemosphere. 248, 125985.

[15] Cai, Z., Huang, L., Quan, X., Zhao, Z., Shi, Y., Puma, G.L., 2020b. Acetate production from inorganic carbon $\left(\mathrm{HCO}_{3}^{-}\right)$in photo-assisted biocathode microbial electrosynthesis systems using $\mathrm{WO}_{3} / \mathrm{MoO}_{3} / \mathrm{g}_{-} \mathrm{C}_{3} \mathrm{~N}_{4}$ heterojunctions and Serratia marcescens species. Appl. Catal., B. 267, 118611.

[16] Chen, L., Tremblay, P.L., Mohanty, S., Xu, K., Zhang, T., 2016. Electrosynthesis of acetate from $\mathrm{CO}_{2}$ by a highly structured biofilm assembled with reduced graphene oxide-tetraethylene pentamine. J. Mater. Chem. A. 4(21), 8395-8401.

[17] Chen, Y., Ji, W., Yan, K., Gao, J., Zhang, J., 2019. Fuel cell-based selfpowered electrochemical sensors for biochemical detection. Nano Energy. 61, 173-193

[18] Chen, Y., Yang, Z., Zhang, Y., Xiang, Y., Xu, R., Jia, M., Cao, J., Xiong, W., 2020. Effects of different conductive nanomaterials on anaerobic digestion process and microbial community of sludge. Bioresour. Technol. 304, 123016.

[19] Cho, J.H., Gao, Y., Choi, S., 2019. A portable, single-use, paper-based microbial fuel cell sensor for rapid, on-site water quality monitoring. Sensors. 19(24), 5452.

[20] Choi, Y.J., Mohamed, H.O., Park, S.G., Al Mayyahi, R.B., AlDhaifallah, M., Rezk, H., Ren, X., Yu, H., Chae, K.J., 2020. Electrophoretically fabricated nickel/nickel oxides as cost effective nanocatalysts for the oxygen reduction reaction in air-cathode microbial fuel cell. Int. J. Hydrogen Energy. 45(10), 5960-5970.

[21] Chouler, J., Cruz-Izquierdo, Á., Rengaraj, S., Scott, J.L., Di Lorenzo, M., 2018. A screen-printed paper microbial fuel cell biosensor for detection of toxic compounds in water. Biosens. Bioelectron. 102, 49-56.

[22] Ci, J., Cao, C., Kuga, S., Shen, J., Wu, M., Huang, Y., 2017. Improved performance of microbial fuel cell using esterified corncob cellulose nanofibers to fabricate air-cathode gas diffusion layer. ACS Sustain Chem. Eng. 5(11), 9614-9618.

[23] Ci, S., Cai, P., Wen, Z., Li, J., 2015. Graphene-based electrode materials for microbial fuel cells. Sci. China Mater. 58(6), 496-509.

[24] Cui, Y., Lai, B., Tang, X., 2019. Microbial fuel cell-based biosensors. Biosensors. 9(3), 92.

[25] Di Palma, L., Bavasso, I., Sarasini, F., Tirillò, J., Puglia, D. Dominici, F., Torre, L., 2018. Synthesis, characterization and performance evaluation of $\mathrm{Fe}_{3} \mathrm{O}_{4} / \mathrm{PES}$ nano composite membranes for microbial fuel cell. Eur. Polym. J. 99, 222-229.

[26] Dizge, N., Unal, B.O., Arikan, E.B., Karagunduz, A., Keskinler, B., 2019. Recent progress and developments in membrane materials for microbial electrochemistry technologies: a review. Bioresour. Technol. Rep. 8, 100308.

[27] Do, M.H., Ngo, H.H., Guo, W., Chang, S.W., Nguyen, D.D., Liu, Y., Varjani, S., Kumar, M., 2020. Microbial fuel cell-based biosensor for online monitoring wastewater quality: A critical review. Sci. Total Environ. 712, 135612.

[28] Duarte, K.D., Frattini, D., Kwon, Y., 2019. High performance yeastbased microbial fuel cells by surfactant-mediated gold nanoparticles grown atop a carbon felt anode. Appl. Energy. 256, 113912.

[29] Elangovan, M., Dharmalingam, S., 2016. A facile modification of a polysulphone based anti biofouling anion exchange membrane for microbial fuel cell application. RSC Adv. 6(25), 20571-20581.

[30] Feng, C., Tsai, C.C., Ma, C.Y., Yu, C.P., Hou, C.H., 2017. Integrating cost-effective microbial fuel cells and energy-efficient capacitive deionization for advanced domestic wastewater treatment. Chem. Eng. J. 330, 1-10.

[31] Ghasemi, M., Daud, W.R.W., Hassan, S.H., Oh, S.E., Ismail, M. Rahimnejad, M., Jahim, J.M., 2013. Nano-structured carbon as electrode material in microbial fuel cells: a comprehensive review. J. Alloys Compd. 580, 245-255.

[32] Han, S., Liu, H., Zhou, C., Ying, H.J., 2019. Growth of carbon nanotubes on graphene as 3D biocathode for NAD+/NADH balance model and high-rate production in microbial electrochemical synthesis from CO 2. J. Mater. Chem. A. 7(3), 1115-1123.

[33] He, Y.R., Du, F., Huang, Y.X., Dai, L.M., Li, W.W., Yu, H.Q., 2016 Preparation of microvillus-like nitrogen-doped carbon nanotubes as the cathode of a microbial fuel cell. J. Mater. Chem. A 4(5), 16321636.

[34] Hernández, L.A., Riveros, G., González, D.M., Gacitua, M., del Valle, M.A., 2019. PEDOT/graphene/nickel-nanoparticles composites as electrodes for microbial fuel cells. J. Mater. Sci.: Mater. Electron. 30(13), 12001-12011.

[35] Hindatu, Y., Annuar, M., Gumel, A., 2017. Mini-review: Anode modification for improved performance of microbial fuel cell Renew. Sustain. Energy Rev. 73, 236-248.

[36] Holder, S.L., Lee, C.H., Popuri, S.R., 2017. Simultaneous wastewater treatment and bioelectricity production in microbial fuel cells using cross-linked chitosan-graphene oxide mixed-matrix membranes. Environ. Sci. Pollut. Res. 24(15), 13782-13796.

[37] Hong, S.-Y., Park, S.-M., 2005. Electrochemistry of conductive polymers $36 . \mathrm{pH}$ dependence of polyaniline conductivities studied by current-sensing atomic force microscopy. J. Phys. Chem. B 109(19), 9305-9310.

[38] Hu, M., Li, X., Xiong, J., Zeng, L., Huang, Y., Wu, Y., Cao, G., Li, W., 2019. Nano-Fe $\mathrm{C} @$ PGC as a novel low-cost anode electrocatalyst for superior performance microbial fuel cells. Biosens. Bioelectron. 142, 111594

[39] Huang, L., Li, X., Ren, Y., Wang, X., 2016. In-situ modified carbon cloth with polyaniline/graphene as anode to enhance performance of microbial fuel cell. Int. J. Hydrogen Energy. 41(26), 11369-11379.

[40] Ivars-Barceló, F., Zuliani, A., Fallah, M., Mashkour, M., Rahimnejad, M., Luque, R., 2018. Novel applications of microbial fuel cells in sensors and biosensors. Appl. Sci. 8(7), 1184

[41] Izadi, P., Rahimnejad, M., Ghoreyshi, A., 2015. Power production and wastewater treatment simultaneously by dual-chamber microbial fuel cell technique. Biotechnol. Appl. Biochem. 62(4), 483-488. 
[42] Jiang, L., Chen, J., Han, D., Chang, S., Yang, R., An, Y., Liu, Y., Chen, F., 2020. Potential of core-shell NiFe layered double hydroxide@ $\mathrm{Co}_{3} \mathrm{O}_{4}$ nanostructures as cathode catalysts for oxygen reduction reaction in microbial fuel cells. J. Power Sources 453, 227877.

[43] Jiang, Z., Zhang, D., Zhou, L., Deng, D., Duan, M., Liu, Y., 2018. Enhanced catalytic capability of electroactive biofilm modified with different kinds of carbon nanotubes. Anal. Chim. Acta. 1035, 51-59.

[44] Kannan, M., 2016. Current status, key challenges and its solutions in the design and development of graphene based ORR catalysts for the microbial fuel cell applications. Biosens. Bioelectron. 77, 1208-1220.

[45] Kaur, R., Marwaha, A., Chhabra, V.A., Kim, K.H., Tripathi, S., 2020. Recent developments on functional nanomaterial-based electrodes for microbial fuel cells. Renew. Sustain. Energy Rev. 119, 109551

[46] Kharkwal, S., Tan, Y.C., Lu, M., Ng, H.Y., 2017. Development and longterm stability of a novel microbial fuel cell BOD sensor with $\mathrm{MnO}_{2}$ catalyst. Int. J. Mol. Sci. 18(2), 276.

[47] Kim, K.Y., Yang, W., Evans, P.J., Logan, B.E., 2016. Continuous treatment of high strength wastewaters using air-cathode microbial fuel cells. Bioresour. Technol. 221, 96-101

[48] Kiran, V., Gaur, B., 2013. Microbial fuel cell: technology for harvesting energy from biomass. Rev. Chem. Eng. 29(4), 189-203.

[49] Kodali, M., Herrera, S., Kabir, S., Serov, A., Santoro, C., Ieropoulos, I., Atanassov, P., 2018. Enhancement of microbial fuel cell performance by introducing a nanocomposite cathode catalyst. Electrochim. Acta. 265, $56-64$.

[50] Kugarajah, V., Dharmalingam, S., 2020. Investigation of a cation exchange membrane comprising Sulphonated Poly Ether Ether Ketone and Sulphonated Titanium Nanotubes in Microbial Fuel Cell and preliminary insights on microbial adhesion. Chem. Eng. J. 398, 125558.

[51] Kugarajah, V., Dharmalingam, S., 2021. Effect of silver incorporated sulphonated poly ether ether ketone membranes on microbial fuel cell performance and microbial community analysis. Chem. Eng. J. 415, 128961

[52] Leong, J.X., Daud, W.R.W., Ghasemi, M., Ahmad, A., Ismail, M., Liew, K.B., 2015. Composite membrane containing graphene oxide in sulfonated polyether ether ketone in microbial fuel cell applications. Int. J. Hydrogen Energy. 40(35), 11604-11614.

[53] Li, Q., Fu, Q., Kobayashi, H., He, Y., Li, Z., Li, J., Liao, Q., Zhu, X., 2020. GO/PEDOT modified biocathode promoting $\mathrm{CO}_{2}$ reduction to $\mathrm{CH}_{4}$ in microbial electrosynthesis. Sustain. Energy Fuels. 4(6), 2987-2997.

[54] Liew, K.B., Leong, J.X., Daud, W.R.W., Ahmad, A., Hwang, J.J., Wu, W., 2020. Incorporation of silver graphene oxide and graphene oxide nanoparticles in sulfonated polyether ether ketone membrane for power generation in microbial fuel cell. J. Power Sources. 449, 227490.

[55] Liu, Q., Zhou, Y., Chen, S., Wang, Z., Hou, H., Zhao, F., 2015. Cellulosederived nitrogen and phosphorus dual-doped carbon as high performance oxygen reduction catalyst in microbial fuel cell. J. Power Sources. 273, $1189-1193$

[56] Liu, W., Zhou, Z., Yin, L., Zhu, Y., Zhao, J., Zhu, B., Zheng, L., Jin, Q., Wang, L., 2018. A novel self-powered bioelectrochemical sensor based on $\mathrm{CoMn}_{2} \mathrm{O}_{4}$ nanoparticle modified cathode for sensitive and rapid detection of hydrogen peroxide. Sens. Actuators, B. 271, 247-255.

[57] Liu, Y., Zhang, X., Zhang, Q., Li, C., 2020. Microbial fuel cells: Nanomaterials based on anode and their application. Energy Technol. 8(9), 2000206

[58] Liu, Z., Ge, B., Li, K., Zhang, X., Huang, K., 2016. The excellent performance and mechanism of activated carbon air cathode doped with different type of cobalt for microbial fuel cells. Fuel 176, 173-180.

[59] Logan, B.E., 2009. Exoelectrogenic bacteria that power microbial fuel cells. Nat. Rev. Microbiol. 7(5), 375-381.

[60] Logan, B.E., Hamelers, B., Rozendal, R., Schröder, U., Keller, J., Freguia, S., Aelterman, P., Verstraete, W., Rabaey, K., 2006. Microbial fuel cells: methodology and technology. Environ. Sci. Technol. 40(17), $5181-5192$

[61] Logan, B.E., Rossi, R., Saikaly, P.E., 2019. Electroactive microorganisms in bioelectrochemical systems. Nat. Rev. Microbiol. 17(5), 307-319.
[62] Logan, B.E., Wallack, M.J., Kim, K.Y., He, W., Feng, Y., Saikaly, P.E., 2015. Assessment of microbial fuel cell configurations and power densities. Environ. Sci. Technol. Letters. 2(8), 206-214.

[63] Lu, L., Xing, D., Ren, Z.J., 2015. Microbial community structure accompanied with electricity production in a constructed wetland plant microbial fuel cell. Bioresour. Technol. 195, 115-121.

[64] Lv, C., Liang, B., Zhong, M., Li, K., Qi, Y., 2019. Activated carbonsupported multi-doped graphene as high-efficient catalyst to modify air cathode in microbial fuel cells. Electrochim. Acta. 304, 360-369.

[65] Ma, M., You, S., Gong, X., Dai, Y., Zou, J., Fu, H., 2015. Silver/iron oxide/graphitic carbon composites as bacteriostatic catalysts for enhancing oxygen reduction in microbial fuel cells. J. Power Sources. $283,74-83$.

[66] Mashkour, M., Kimura, T., Kimura, F., Mashkour, M., Tajvidi, M., 2013. Tunable self-assembly of cellulose nanowhiskers and polyvinyl alcohol chains induced by surface tension torque. Biomacromolecules. 15(1), 60-65.

[67] Mashkour, M., Kimura, T., Mashkour, M., Kimura, F., Tajvidi, M., 2018. Printing birefringent figures by surface tension-directed selfassembly of a cellulose nanocrystal/polymer ink components. ACS Appl. Mater. Interfaces. 11(1), 1538-1545.

[68] Mashkour, M., Rahimnejad, M., 2015. Effect of various carbon-based cathode electrodes on the performance of microbial fuel cell. Biofuel Res. J. 2, 296-300.

[69] Mashkour, M., Rahimnejad, M., Mashkour, M., 2016. Bacteria cellulose-polyaniline nano-biocomposite: a porous media hydroge bioanode enhancing the performance of microbial fuel cell. J. Power Sources. 325, 322-328.

[70] Mashkour, M., Rahimnejad, M., Mashkour, M., Bakeri, G., Luque, R., Oh, S.E., 2017a. Application of wet nanostructured bacterial cellulose as a novel hydrogel bioanode for microbial fuel cells. ChemElectroChem. 4(3), 648-654.

[71] Mashkour, M., Rahimnejad, M., Pourali, S., Ezoji, H., ElMekawy, A., Pant, D., 2017b. Catalytic performance of nano-hybrid graphene and titanium dioxide modified cathodes fabricated with facile and green technique in microbial fuel cell. Prog. Nat. Sci.: Mater. Int 27(6), 647-651.

[72] Mashkour, M., Rahimnejad, M., Mashkour, M., Soavi, F., 2020 Electro-polymerized polyaniline modified conductive bacterial cellulose anode for supercapacitive microbial fuel cells and studying the role of anodic biofilm in the capacitive behavior. J. Power Sources. 478, 228822

[73] Mashkour, M., Rahimnejad, M., Mashkour, M., Soavi, F., 2021 Increasing bioelectricity generation in microbial fuel cells by a highperformance cellulose-based membrane electrode assembly. Appl. Energy. 282, 116150

[74] Masoudi, M., Rahimnejad, M., Mashkour, M., 2021. Enhancing operating capacity of microbial fuel cells by using low-cost electrodes and multi anode-cathode connections in a membrane-less configuration. Int. J. Hydrogen Energy. 46 (11) 8226-8238.

[75] Masoudi, M., Rahimnejad, M., Mashkour, M., 2020. Fabrication of anode electrode by a novel acrylic based graphite paint on stainless steel mesh and investigating biofilm effect on electrochemical behavior of anode in a single chamber microbial fuel cell. Electrochim. Acta. 344, 136168.

[76] Mouhib, M., Antonucci, A., Reggente, M., Amirjani, A., Gillen, A.J., Boghossian, A.A., 2019. Enhancing bioelectricity generation in microbial fuel cells and biophotovoltaics using nanomaterials. Nano Res. 12(9), 2184-2199.

[77] Munoz-Cupa, C., Hu, Y., Xu, C.C., Bassi, A., 2020. An overview of microbial fuel cell usage in wastewater treatment, resource recovery and energy production. Sci. Total Environ. 754, 142429.

[78] Nambiar, S., Togo, C., Limson, J., 2009. Application of multi-walled carbon nanotubes to enhance anodic performance of an Enterobacter cloacae-based fuel cell. Afr. J. Biotechnol. 8(24).

[79] Narayanasamy, S., Jayaprakash, J., 2020. Application of carbonpolymer based composite electrodes for Microbial fuel cells. Rev. Environ. Sci. Biotechnol. 19, 595-620. 
[80] Noori, M.T., Tiwari, B., Mukherjee, C., Ghangrekar, M., 2018. Enhancing the performance of microbial fuel cell using AgPt bimetallic alloy as cathode catalyst and anti-biofouling agent. Int. J. Hydrogen Energy. 43(42), 19650-19660.

[81] Olabi, A., Wilberforce, T., Sayed, E.T., Elsaid, K., Rezk, H., Abdelkareem, M.A., 2020. Recent progress of graphene based nanomaterials in bioelectrochemical systems. Sci. Total Environ. 749, 141225.

[82] Palanisamy, G., Jung, H.Y., Sadhasivam, T., Kurkuri, M.D., Kim, S.C., Roh, S-H., 2019. A comprehensive review on microbial fuel cell technologies: Processes, utilization, and advanced developments in electrodes and membranes. J. Cleaner Prod. 221, 598-621.

[83] Patel, N., Rai, D., Chauhan, D., Shahane, S., Mishra, U., Bhunia, B., 2019. Carbon nanotube based anodes and cathodes for microbial fuel cells. Microbial Fuel Cells: Materials and Applications. Materials Research Forum LLC, 46, 125-150.

[84] Pattanayak, P., Papiya, F., Pramanik, N., Kundu, P.P., 2019. Deposition of $\mathrm{Ni}-\mathrm{NiO}$ nanoparticles on the reduced graphene oxide filled polypyrrole: evaluation as cathode catalyst in microbial fuel cells. Sustain. Energy Fuels. 3(7), 1808-1826.

[85] Peera, S.G., Maiyalagan, T., Liu, C., Ashmath, S., Lee, T.G., Jiang, Z., Mao, S., 2021. A review on carbon and non-precious metal based cathode catalysts in microbial fuel cells. Int. J. Hydrogen Energy. 46(4), 30563089

[86] Salar-García, M., Ortiz-Martínez, V., 2019. Nanotechnology for wastewater treatment and bioenergy generation in microbial fuel cells. Advanced Research in Nanosciences for Water Technology. Springer, pp. 341-362.

[87] San-Martín, M.I., Sotres, A., Alonso, R.M., Díaz-Marcos, J., Morán, A., Escapa, A., 2019. Assessing anodic microbial populations and membrane ageing in a pilot microbial electrolysis cell. Int. J. Hydrogen Energy. 44(32), 17304-17315.

[88] Santoro, C., Artyushkova, K., Babanova, S., Atanassov, P., Ieropoulos, I., Grattieri, M., Cristiani, P., Trasatti, S., Li, B., Schuler, A.J., 2014. Parameters characterization and optimization of activated carbon (AC) cathodes for microbial fuel cell application. Bioresour. Technol. 163, 5463.

[89] Shabani, M., Younesi, H., Pontié, M., Rahimpour, A., Rahimnejad, M., Zinatizadeh, A.A., 2020. A critical review on recent proton exchange membranes applied in microbial fuel cells for renewable energy recovery. J. Cleaner Prod. 264, 121446.

[90] Shabani, M., Younesi, H., Rahimpour, A., Rahimnejad, M., 2019. Upgrading the electrochemical performance of graphene oxide-blended sulfonated polyetheretherketone composite polymer electrolyte membrane for microbial fuel cell application. Biocatal. Agric. Biotechnol. 22, 101369.

[91] Sivasankaran, A., Sangeetha, D., 2015. Influence of sulfonated $\mathrm{SiO}_{2}$ in sulfonated polyether ether ketone nanocomposite membrane in microbial fuel cell. Fuel. 159, 689-696.

[92] Tang, H., Cai, S., Xie, S., Wang, Z., Tong, Y., Pan, M., Lu, X., 2016. Metal-organic-framework-derived dual metal-and nitrogen-doped carbon as efficient and robust oxygen reduction reaction catalysts for microbial fuel cells. Adv. Sci. 3(2), 1500265.

[93] Tiwari, A.K., Jain, S., Mungray, A.A., Mungray, A.K., 2020. $\mathrm{SnO}_{2}$ : PANI modified cathode for performance enhancement of air-cathode microbial fuel cell. J. Environ. Chem. Eng. 8(1), 103590.

[94] Tofighi, A., Rahimnejad, M., Ghorbani, M., 2019. Ternary nanotube $\alpha$ $\mathrm{MnO}_{2} / \mathrm{GO} / \mathrm{AC}$ as an excellent alternative composite modifier for cathode electrode of microbial fuel cell. J. Therm. Anal. Calorim. 135(3), 16671675

[95] Truong, D.H., Dam, M.S., Bujna, E., Rezessy-Szabo, J., Farkas, C., Vi, V.N.H., Csernus, O., Nguyen, V.D., Gathergood, N., Friedrich, L., 2021. In situ fabrication of electrically conducting bacterial cellulosepolyaniline-titanium-dioxide composites with the immobilization of Shewanella xiamenensis and its application as bioanode in microbial fuel cell. Fuel. 285, 119259.

[96] Valipour, A., Ayyaru, S., Ahn, Y., 2016. Application of graphene-based nanomaterials as novel cathode catalysts for improving power generation in single chamber microbial fuel cells. J. Power Sources. 327, 548-556.
[97] Wang, R., Li, H., Sun, J., Zhang, L., Jiao, J., Wang, Q., Liu, S., 2021. Nanomaterials Facilitating Microbial Extracellular Electron Transfer at Interfaces. Adv. Mater. 33(6), 2004051.

[98] Wang, Y., Zhong, K., Huang, Z., Chen, L., Dai, Y., Zhang, H., Su, M., Yan, J., Yang, S., Li, M., 2020. Novel g- $\mathrm{C}_{3} \mathrm{~N}_{4}$ assisted metal organic frameworks derived high efficiency oxygen reduction catalyst in microbial fuel cells. J. Power Sources. 450, 227681.

[99] Xiao, N., Wu, R., Huang, J.J., Selvaganapathy, P.R., 2020. Anode surface modification regulates biofilm community population and the performance of micro-MFC based biochemical oxygen demand sensor. Chem. Eng. Sci. 221, 115691.

[100]Xu, L., Zhao, Y., Doherty, L., Hu, Y., Hao, X., 2016. The integrated processes for wastewater treatment based on the principle of microbial fuel cells: a review. Crit. Rev. Environ. Sci. Technol. 46(1), 60-91

[101]Xu, Q., Wang, L., Li, C., Wang, X., Li, C., Geng, Y., 2019. Study on improvement of the proton conductivity and anti-fouling of proton exchange membrane by doping $\mathrm{SGO} @ \mathrm{SiO}_{2}$ in microbial fuel cel applications. Int. J. Hydrogen Energy. 44(29), 15322-15332.

[102]Xue, W., Zhou, Q., Li, F., 2020. The feasibility of typical metalorganic framework derived $\mathrm{Fe}, \mathrm{Co}, \mathrm{N}$ co-doped carbon as a robust electrocatalyst for oxygen reduction reaction in microbial fuel cell. Electrochim. Acta. 355, 136775

[103]Yang, E., Chae, K.J., Alayande, A.B., Kim, K.Y., Kim, I.S., 2016. Concurrent performance improvement and biofouling mitigation in osmotic microbial fuel cells using a silver nanoparticle-polydopamine coated forward osmosis membrane. J. Membr. Sci. 513, 217-225.

[104]Yang, W., Chata, G., Zhang, Y., Peng, Y., Lu, J.E., Wang, N. Mercado, R., Li, J., Chen, S., 2019. Graphene oxide-supported zinc cobalt oxides as effective cathode catalysts for microbial fuel cell: High catalytic activity and inhibition of biofilm formation. Nano Energy. 57, 811-819.

[105] Yang, Q., Yang, S., Liu, G., Zhou, B., Yu, X., Yin, Y., Yang, J., Zhao H., 2021. Boosting the anode performance of microbial fuel cells with a bacteria-derived biological iron oxide/carbon nanocomposite catalyst. Chemosphere. 268, 128800.

[106]Yin, T., Zhang, H., Yang, G., Wang, L., 2019. Polyaniline composite $\mathrm{TiO}_{2}$ nanosheets modified carbon paper electrode as a high performance bioanode for microbial fuel cells. Synth. Met. 252, 8-14

[107]Zeng, L., Li, X., Shi, Y., Qi, Y., Huang, D., Tadé, M., Wang, S., Liu, S., 2017. $\mathrm{FePO}_{4}$ based single chamber air-cathode microbial fuel cell for online monitoring levofloxacin. Biosens. Bioelectron. 91, 367 373.

[108]Zhang, Y., Jiang, J., Zhao, Q., Wang, K., Yu, H., 2018a. Analysis of functional genomes from metagenomes: Revealing the accelerated electron transfer in microbial fuel cell with rhamnolipid addition. Bioelectrochemistry. 119, 59-67.

[109]Zhang, P., Liu, J., Qu, Y., Li, D., He, W., Feng, Y., 2018b. Nanomaterials for facilitating microbial extracellular electron transfer: Recent progress and challenges. Bioelectrochemistry. 123, $190-200$

[110]Zhang, L., Hu, Y., Chen, J., Huang, W., Cheng, J., Chen, Y., 2018c A novel metal organic framework-derived carbon-based catalyst for oxygen reduction reaction in a microbial fuel cell. J. Power Sources. 384, 98-106

[111]Zhang, S., Su, W., Wang, X., Li, K., Li, Y., 2019. Bimetallic metalorganic frameworks derived cobalt nanoparticles embedded in nitrogen-doped carbon nanotube nanopolyhedra as advanced electrocatalyst for high-performance of activated carbon air-cathode microbial fuel cell. Biosens. Bioelectron. 127, 181-187.

[112]Zhao, C.E., Qiu, Z., Yang, J., Huang, Z.D., Shen, X., Li, Y., Ma, Y. 2020. Metal-organic frameworks-derived core/shell porous carbon materials interconnected by reduced graphene oxide as effective cathode catalysts for microbial fuel cells. ACS Sustain. Chem. Eng. 8(37), 13964-13972.

[113]Zhong, K., Huang, L., Li, M., Dai, Y., Wang, Y., Zuo, J., Zhang, H. Zhang, B., Yang, S., Tang, J., 2019. Cobalt/nitrogen-Co-doped nanoscale hierarchically porous composites derived from octahedral 
metal-organic framework for efficient oxygen reduction in microbial fuel cells. Int. J. Hydrogen Energy. 44(57), 30127-30140.

[114]Zhong, M., Liang, B., Fang, D., Li, K., Lv, C., 2021. Leaf-like carbon frameworks dotted with carbon nanotubes and cobalt nanoparticles as robust catalyst for oxygen reduction in microbial fuel cell. J. Power Sources. 482, 229042.

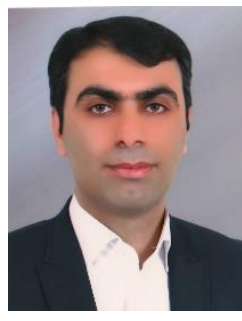

Mostafa Rahimnejad obtained his Ph.D in biochemical engineering from the University of Mazandran, Iran, in 2011. He is now a full professor in Biochemical Engineering at Babol Noshirvani University of Technology (BNUT) (Iran). Mostafa is the head of Biofuel \& Renewable Energy Research Center at the Faculty of Chemical Engineering in BNUT. He has also served as the Director General of the Scientific Collaborations \& International Affairs at BNUT since June 2016. His research interests are in experimental biochemical engineering and fermentation technology, primarily biological fuel cells. He has published over 180 research articles, filed 9 patent applications, and edited 4 books. Dr. Rahimnejad has delivered numerous invited, guest, and keynote lectures in different universities. He was awarded the Young Researcher Award by BIOVISION (TWAS 2013 \& 2015), Top Elite Researcher in Mazandran province, Iran (2013), and Top Researcher Award by BNUT (2015).

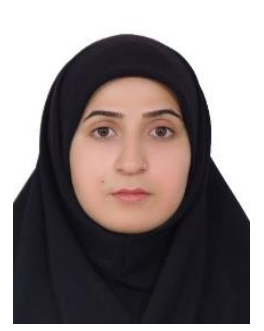

Nahid Navidjouy is an Assistant Professor at Urmia University of Medical Sciences (Iran) since 2007. She received her Ph.D. in Environmental Health Engineering from the University of Hamadan, Iran (2019). Nahid worked on applying three-chamber microbial fuel cells to remove ammonium and organic materials from water and wastewater with Prof. Mostafa Rahimnejad. She also worked on the factors affecting the performance of microbial fuel cells used mitigating pollutants. Her current research interests reside in applying bioelectrochemical systems and microbial fuel cells using nanomaterials to improve the removal of environmental pollutants and generate bioenergy.
[115]Zhu, J., Wang, J., Hou, J., Zhang, Y., Liu, J., Van der Bruggen, B. 2017. Graphene-based antimicrobial polymeric membranes: a review. J. Mater. Chem. A 5(15), 6776-6793.

[116]Zhu, W., Yao, M., Gao, H., Wen, H., Zhao, X., Zhang, J., Bai, H., 2019. Enhanced extracellular electron transfer between Shewanella putrefaciens and carbon felt electrode modified by bio-reduced graphene oxide. Sci. Total Environ. 691, 1089-1097.

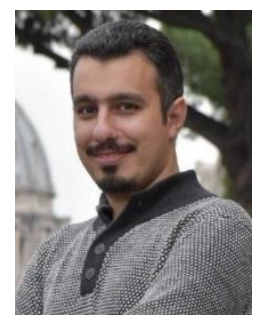

Mehrdad Mashkour was born in Gorgan, Iran (1990). He received his dual Ph.D in Biochemical Engineering and Inorganic Chemistry in 2021 from the Babol Noshirvani University of Technology (BNUT) (Iran) and the Alma Mater Studiorum Università di Bologna (Italy), respectively. Mehrdad worked on fabricating cellulosic electrodes for microbial fuel cells with Prof. Mostafa Rahimnejad and Prof. Mahdi Mashkour (Iran) and then joined the research group led by Prof. Francesca Soavi (Italy) to work on supercapacitors. His current research interests reside in the application of nanocellulosic materials in energy storage devices and supercapacitive bioelectrochemical systems.

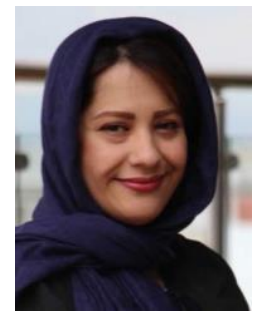

Fereshteh Raouf was born in Rasht, Iran, in 1982. She received her Bachelor (2004), Master (2007), and Ph.D. (2015) in Chemical Engineering from Mazandaran University, Iran. During her MSc., Fereshteh worked on DME synthesis in a collaborative project with the Iranian Research Organization for Science and Technology. She conducted her Ph.D. research with the OCM Research Team at the Iran Polymer and Petrochemical Institute. Since 2015, Dr. Raouf has been an Assistant Professor of the Department of Chemical Engineering at the University of Guilan. Her research is focused on the synthesis of nanocomposite adsorbents for removing organic and inorganic pollutants from aquatic media. 